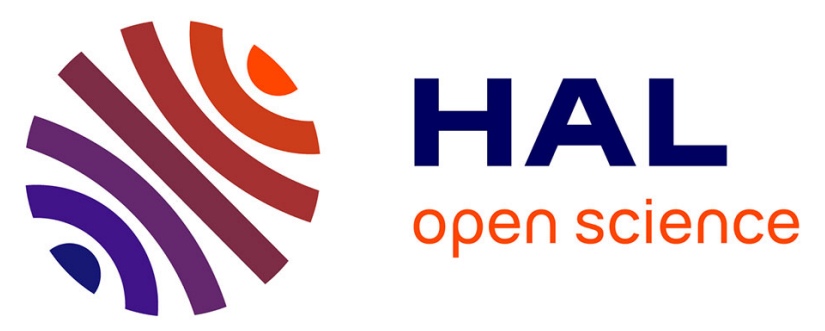

\title{
Drug carrier systems made from self-assembled glyco-nanoparticles of maltoheptaose-b-polyisoprene enhanced the distribution and activity of curcumin against cancer cells
}

Bárbara Sthéfani Caldas, Danielle Lazarin-Bidóia, Celso Vataru Nakamura, Sami Halila, Redouane Borsali, Edvani Curti Muniz

\section{To cite this version:}

Bárbara Sthéfani Caldas, Danielle Lazarin-Bidóia, Celso Vataru Nakamura, Sami Halila, Redouane Borsali, et al.. Drug carrier systems made from self-assembled glyco-nanoparticles of maltoheptaoseb-polyisoprene enhanced the distribution and activity of curcumin against cancer cells. Journal of Molecular Liquids, 2020, 309, pp.113022. 10.1016/j.molliq.2020.113022 . hal-02948775

\section{HAL Id: hal-02948775 \\ https://hal.science/hal-02948775}

Submitted on 10 Nov 2020

HAL is a multi-disciplinary open access archive for the deposit and dissemination of scientific research documents, whether they are published or not. The documents may come from teaching and research institutions in France or abroad, or from public or private research centers.
L'archive ouverte pluridisciplinaire HAL, est destinée au dépôt et à la diffusion de documents scientifiques de niveau recherche, publiés ou non, émanant des établissements d'enseignement et de recherche français ou étrangers, des laboratoires publics ou privés. 


\title{
Drug carrier systems made from self-assembled glyco- nanoparticles of maltoheptaose-b-polyisoprene enhanced the distribution and activity of curcumin against cancer cells
}

\author{
Bárbara Sthéfani Caldas ${ }^{a, b}$, Danielle Lazarin-Bidóia ${ }^{c}$, Celso Vataru Nakamura ${ }^{c}$, Sami Halila ${ }^{\text {a }}$, Redouane Borsali \\ ${ }^{a, *}$, Edvani Curti Muniz b,d,e,** \\ a Univ. Grenoble Alpes, CNRS, CERMAV, BP53, 38041 Grenoble Cedex 9, France \\ b Departamento de Química, Universidade Estadual de Maringá - UEM, Av. Colombo, 5790 - Zona 7, 87020- \\ 900 Maringá, PR, Brazil c Laboratório de Inovação Tecnológica no Desenvolvimento de Fármacos e Cosméticos, \\ Departamento de Ciências Básicas da Saúde, UEM, Av. Colombo, 5790 - Zona 7, 87020-900 Maringá, PR, \\ Brazil \\ d Universidade Tecnológica Federal do Paraná - UTFPR, Avenida dos Pioneiros, 3131, 86036-370, Londrina, PR, \\ Brazil e Departamento de Química, Universidade Federal do Piauí - UFPI, Campus Petrônio Portella, Bairro \\ Ininga, 64049-550 Teresina, Brazil
}

\section{Abstract}

Controlled self-assembly of polymeric systems behave according to their composition and physicalchemical properties. Inclusion of a guest molecule may influence interactions and response to the media and to other surfaces and bodies, for example, cells. Hence, loading the polymeric system with curcumin (CUR), a natural and anticancer drug, confer interesting features to the carrier material. Micelle formation was achieved, in aqueous solution of carbohydrate-based block copolymer consisting in maltoheptaose-block-polyisoprene $\left(\mathrm{MH}-b-\mathrm{PI}_{3.8 \mathrm{ka}}\right)$, by adding a large amount of water (a selective solvent for maltoheptaose, $\mathrm{MH})$ into a solution of well-dissolved $\mathrm{MH}-\mathrm{b}-\mathrm{PI} \mathrm{I}_{3.8 \mathrm{kDa}}\left(\mathrm{THF} / \mathrm{H}_{2} \mathrm{O}\right.$ 9:1 $(\% \mathrm{w} / \mathrm{w})]$. Morphology and size (ca. $89 \mathrm{~nm}$ ) of these glyco-nanoparticles were characterized using light scattering (static and dynamic modes - SLS and DLS) complemented by nanoparticle tracking analysis (NTA), transmission electron microscopy (TEM) and atomic force microscopy (AFM). The lyophilization efficiency was confirmed by measuring the relation between final and initial diameters $\left(\mathrm{S}_{\mathrm{f}} / \mathrm{S}_{\mathrm{i}}\right)$. CUR was successfully loaded into the nanoparticles with an entrapment efficiency of ca. $70 \%$. CUR-charged nanoparticles showed stability into simulated gastric and intestinal fluids. Such micelles served as drug delivery system to carry CUR and presented a great role in wiping out unhealthy cells from many sorts.

\section{Introduction}

Cancer, is still one of the main causes of human death in spite of the existence of treatments like surgery techniques, chemotherapy and radiotherapy used to its removal [1]. Chemo- and radiotherapy resistances, as well as MDR (multidrug resistance) effects, which involves different mechanisms, are 
common causes of failure in cancer treatment $[2,3]$. Conventional methodologies used in cancer treatment do not show sometimes good efficiency in prognosis due to the weak solubility of the applied medicines in physiological media, affecting their distribution and, consequently, reducing their bioavailability $[\underline{4}, 5]$.

Nanomedicine is a science which has freshly showed up to combine nanotechnology advances to clinical applications [6]. Nanotherapeutic technologies may develop diverse products improving the clinical outcome and enhancing the efficacy and tolerability of drugs [7].

For example, curcumin (CUR) or 1,7-bis(4-hydroxy-3-methoxyphenyl)-1,6-heptadiene-3,5-dione is a lipophilic molecule and a natural dye that is an active component from Curcuma longa. CUR possesses evidenced activities as antioxidants [], antimicrobial [9], antiviral [10], anticancer [11] and wound healing [12]. More specifically, CUR exhibits anti-proliferative, anti-invasive, anti-angiogenic activities and possesses potential inhibitory effect on cancer invasion and metastasis $[13,14]$. The active principle not only acts like a chemosensitizer that is able to make tumor cells more sensitive to the effects of chemotherapy but it also increases the cytotoxic effect of anti-cancer drugs as for example doxorubicin, carboplatin and cisplatin [15].

Polymeric micelles made of amphiphilic block copolymers are an attractive class of materials which are very interesting for medical application. They self-assemble in aqueous solution onto a myriad of nanostructures sterically stabilized by the hydrophilic blocks and are able to carry drugs poorly soluble in water into the hydrophobic blocks [16].

Nanoprecipitation or solvent displacement method, a technique developed and patented in 1988 by Fessi et al. $[17,18]$, is certainly one of the most used procedure to generate NPs from block copolymers. In this method, a block copolymer remains dissolved in a good solvent (or a solvent mixture) for both, hydrophilic and hydrophobic segments. Then the copolymer solution is added to a selective solvent for the hydrophilic block, usually water, and the good solvent is eliminated by evaporation or dialysis. At that time, the solution containing the block copolymers diffuses into the media forming self-assembled NPs [19].

NP's biocompatibility guarantees the safety to the human health [20]. Petrelli A. et al, for example, prepared oligosaccharide-based block copolymers, which self-assembled into water to form spherical micelles, through an efficient metal-free click-chemistry approach [21]. Following this subject matter, Modolon S. M. et al and Zepon K. M. et al, built NPs shaped as normal and reversed micelles, from block copolymers, which were able to encapsulate guest molecules [22, 23]. Further progress was provided by Mazzarino L. et al. using xyloglucan-b-polycaprolactone to produce micelles NPs. They evaluated the toxicity through in vitro and in in vivo assays. The results did not indicate toxicity effects, being the material able to act as nanocarriers for drug delivery [24]. 
NPs that present hydrophobic surfaces show small plasma circulation times because the fast recognition and elimination by cells of the mononuclear phagocyte system (MPS). Cover NPs with hydrophilic polymers provides a steric stabilization to particles so that they become "invisible" to the phagocytic system enhancing their bioavailability whereas their plasmatic circulation time increases. As longer is the time of circulation, bigger is the NPs probability in reaching their target $[\underline{25}, \underline{26}]$. The aim of this work was to describe the synthesis and self-assembly studies of biocompatible carbohydrate-based block copolymer micelles constituted of a hydrophilic maltoheptaose $(\mathrm{MH})$ block "clicked" to a hydrophobic polyisoprene (PI). This system was assessed for its ability to act as CUR nanocarriers turned to wrestle the cancer. On this scenario, the CUR came as an efficient, more accessible and less expensive drug in comparison with doxorubicin, cisplatin and carboplatin. Maltoheptaose $(\mathrm{MH})$ is a water soluble $[\underline{27}]$ linear $\alpha-(1,4)$ glucan of seven glucosyl units derived from the abundant and plant-biosourced starch and usually obtained from the ring-opening of $\beta$-cyclodextrin [28]. Polyisoprene $(\mathrm{PI})$ is a polymer derived from isoprene, a monomer of terpene structures found in many structures in nature, for example in essential oils and pheromones. Nano-sized PI are internalized by different cell lines due their interaction with the cell wall making them relevant for biomedical application [29].

\section{Experimental}

\subsection{Materials}

Block copolymers ( $\mathrm{MH}-b-\mathrm{PI}_{3.8 \mathrm{kDa}}$ ) were synthesized in our research group, by click chemistry (S1) [30], from commercial building blocks. MH was purchased from Hayashibara - Japan and PI

$\left(M \mathrm{w}=3000 \mathrm{~g} \cdot \mathrm{mol}^{-1}\right)$ from Polymer Source. Curcumin ( $\geq 94 \%$-curcuminoid content; $\geq 80 \%$ - curcumin) was acquired from Sigma Aldrich. Tetrahydrofuran (THF; >99.5\%) was purchased from Across Organics and was used without any purification process. Polytetrafluorethylene (PTFE) hydrophilic filters with $0.45 \mu \mathrm{m}$ pore size and diameter of $25 \mathrm{~mm}$ were bought from Carl Roth (Karlsruhe, Germany). Pure water was obtained by using Milli-Q® system (Billerica, MA, USA).

\subsection{Methods}

2.2.1. Static light scattering (SLS) to determination of solvent optimal conditions

After defining THF as the best organic solvent to well solubilize PI chains, solutions with different proportions of THF/water, from 0 to $100 \%$ in weight, were prepared. The mixtures of solvents stayed under stirring (500 rpm) during $2 \mathrm{~h}$ so that by the addition of $\mathrm{BCP} \mathrm{MH}-b-\mathrm{PI}_{3.8 \mathrm{kDa}}$, solutions at $1.0 \mathrm{mg} \cdot \mathrm{mL}^{-1}$ were prepared. After that, they were further stirred (500 rpm) for a period of $24 \mathrm{~h}$ to reach the equilibrium and subsequently be submitted to three SLS measurements of $120 \mathrm{~s}$ each, in three 
different scattering angles $\left(60^{\circ}, 90^{\circ}\right.$ and $\left.120^{\circ}\right)$. SLS experiments were carried out at room temperature using an ALV laser goniometer, which consists of a $22 \mathrm{~mW}$ HeNe linearly polarized laser operating at a wavelength of $632.8 \mathrm{~nm}$ and an ALV-5000/EPP multiple t digital correlator with $125 \mathrm{~ns}$ initial sampling time. Samples were immersed in a toluene bath under controlled temperature (298 K) after being transferred to a cylindrical cuvette. The scattered intensity was corrected by the solvent signal and normalized by the toluene signal. The scattered volume which changes according to the observation angle was also taken into account. Real intensity of the scattered light $\left(I_{\text {real }}\right)$ was estimated according to Eq. (1), using values acquired by two detectors $(\mathrm{CH} 0$ and $\mathrm{CH} 1)$, light intensity obtained from the equipment $\left(I_{\text {diode }}\right)$, correction factor of the light lost or superposed during the measurement $\left(2 \times 10^{6}\right)$ and the sin of the measurement angles $(\sin \theta) .(1)$ Ireal $=\mathrm{CH} 0+\mathrm{CH} 1 * 2 \times 106$ ldiode $* \sin \theta$

\subsubsection{Obtaining of $\mathrm{MH}-\mathrm{b}-\mathrm{PI}_{3.8 \mathrm{kDa}}$ nanoparticles}

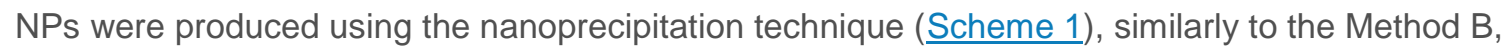
described by Otsuka et al. [19], where $40 \mathrm{~g}$ of Milli- $Q \AA$ water was slowly added (10 min) into $1.0 \mathrm{~g}$ of the $0.5 \mathrm{mg} \cdot \mathrm{mL}^{-1} \mathrm{BCPs}$ solution $\left(\mathrm{THF} / \mathrm{H}_{2} \mathrm{O}[9: 1(\% \mathrm{w} / \mathrm{w})]\right)$, using a Pasteur pipet under stirring (500 rpm). Subsequently, the stirring was maintained during $1.5 \mathrm{~h}$, so that the solution could be filtered through $0.45 \mu \mathrm{m}$ hydrophilic PTFE filters. Afterward, the remaining THF was removed through evaporation and the product was concentrated until $4.0 \mathrm{~g}$ (checked by weighing) under reduced pressure at $309 \mathrm{~K}$.

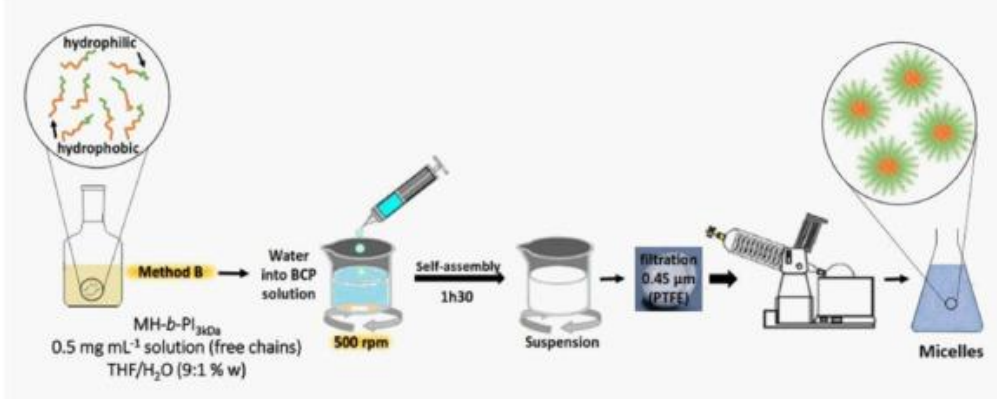

Scheme 1. Stages of Method B used to perform nanoprecipitation reactions to produce NPs.

\subsubsection{Dynamic Light Scattering (DLS) measurements}

DLS experiments were carried out at room temperature using the same equipment applied to proceed SLS analysis (ALV laser goniometer). After appropriated dilution, samples were transferred to a cylindrical cuvette and then immersed in a toluene bath under controlled temperature (298 K). Scattered light was detected by photomultiplier diodes and transformed in data via ALV correlator control software. The module of scattering vector is named $q$ and it is defined by Eq. (2), where $n$ represents the refraction index of pure water, $\theta$ is the scattering angle and $\lambda$ the laser wavelength. $(2) q=4 \pi n \lambda * \sin \theta 2$ 
Each experiment was carried out during $40 \mathrm{~s}$ and the scattered light was measured in different angles varying from $30^{\circ}$ to $150^{\circ}$ in crescent intervals of $10^{\circ}$. Relaxation time distribution was obtained using the CONTIN analysis of the autocorrelation function $\left(g^{2}-1\right)$ frequency. From the linear dependence of the relaxation frequency $(1 / T)$ on the squared wave vector modulus $\left(q^{2}\right)$, the diffusion coefficient $(D)$ of the NPs was calculated. The hydrodynamic radius $\left(R_{h}\right)$ was then obtained from D with the StokesEinstein relation (3), where $\mathrm{K}_{\mathrm{B}}$ represents Boltzmann constant $(\mathrm{J} / \mathrm{K}), \mathrm{T}$ the temperature $(\mathrm{K})$, and $\eta$ the viscosity in pure water $(\eta=0.89 \mathrm{cP}$ at $298 \mathrm{~K})[19,31]$. The NPs suspensions charged or not with CUR did not show absorption at the $\lambda$ of laser $(632.8 \mathrm{~nm}) .(3) \mathrm{Rh}=\mathrm{KBT} 6 \pi \mathrm{mD}$

\subsubsection{Nanoparticle Tracking Analysis (NTA) measurements}

In this technique a class 1 laser (NANOSITE LM10 ${ }^{\mathrm{TM}}$ ) comprises a metallic aluminium box $(92 \times 66 \times 47 \mathrm{~mm})$ containing a monomodal diode laser beam in solid state ( $<20 \mathrm{~mW}, 655 \mathrm{~nm})$ configured to point a finely focused beam through a chamber containing $500 \mu \mathrm{L}$ of sample directly injected using a syringe. Such chamber possesses an optical window built above a stainless steel surface through that allows real time video and tracking of laser-illuminated particles undergoing Brownian motion in suspension $[\underline{32}, \underline{33}]$. Its basis consists of an optical metalized plan especially developed, above which the beam spreads. Particles in the liquid were observed by the microscope as little points reflecting the light, that move quickly. Each video sequence was made at room temperature over $60 \mathrm{~s}$, and images were analysed by the NTA analytical software, version 2.0 which establishes the quadratic mean of the displacement and the diffusional coefficient, so that, particles radius and diameter are obtained from the Stokes-Einstein equation.

\subsubsection{Transmission Electron Microscopy (TEM) observations}

Morphology and size of NPs were examined using an electronic microscope Philips CM200 (FEI Company, USA) operating at $80 \mathrm{kV}$, and images were recorded on Kodak SO163 films. A droplet of NPs suspension $(4 \mu \mathrm{L})$ was deposited in a glow-discharged carbon-coated copper grid. After a few minutes, the liquid in excess was blotted with filter paper. Finally, the sample was negatively stained with $2 \%(w / v)$ uranyl acetate and then submitted to air-drying prior to imaging.

\subsubsection{Atomic Force Microscopy (AFM) observations}

AFM analysis of NPs was settled in an atomic microscope Bruker Icon NanoScope (Bruker Corp., USA). Si substrate with $1.0 \mathrm{~cm}^{2}$, previously sonicated, (acetone and ethanol, $5 \mathrm{~min}$ each), and then washed with distillate water, dried by compressed air and left under plasma by $10 \mathrm{~min}$, so that a $10 \mu \mathrm{L}$ of sample were deposited above the Si substrate by spin coating technique (time $=120 \mathrm{~s}$; speed $=2000 \mathrm{rpm} ;$ moisture $=50 \%$ at $300 \mathrm{~K}$. AFM images were recorded in tapping mode above a 
surface of $1.0 \mu \mathrm{m}^{2}$ and at $0.935 \mathrm{~Hz}$. The resonant frequency and its constant force of the cantilever were $320 \mathrm{kHz}$ and $42 \mathrm{~N} / \mathrm{m}$, respectively. Free software Gwyddion was employed to fit images and obtain NPs diameters.

\subsubsection{Nanoparticles Iyophilisation}

Before freeze-drying process, six different substances were tested as lyoprotectants and mixed at different NP:Iyoprotectant (NP:C) molar ratios (Table 1), Hydroxypropyl- $\beta$-cyclodextrin, sucrose, phosphate buffered saline (PBS), glycerol, ethylene glycol and polyethylene glycol. Once homogenized, the NP samples were frozen with liquid nitrogen $(80 \mathrm{~K})$ and immediately transferred to a Labconco FreeZone 6 lyophilizator (Labconco Corp., USA), which held the samples during $24 \mathrm{~h}$. The condenser temperature and pressure were $223 \mathrm{~K}$ and $0.021 \mathrm{mbar}$, respectively. Dried samples were reconstituted at room temperature with Milli- $Q \AA$ water to their initial concentrations prior to analysis of structure by DLS and TEM. Properties of all reconstituted dispersions were compared to those of the fresh, non-frozen and non-dried formulations. NPs hydrodynamic diameters before $\left(\mathrm{S}_{\mathrm{i}}\right)$ and after $\left(\mathrm{S}_{\mathrm{f}}\right)$ Iyophilization were compared using the relation $S_{f} / S_{i}$ [[34], [35], [36], [37], [38], [39]].

Table 1. Concentration of 6 substances applied as lyoprotectors (LY) and they respective molar ratios, considering nanoparticles (NP/LY).

\begin{tabular}{|c|c|c|c|c|c|c|c|}
\hline$\underset{\left(\mathrm{mg}^{\prime} \cdot \mathrm{mL}^{-1}\right)}{\mathrm{HP \beta CD}}$ & \multicolumn{2}{|c|}{$\begin{array}{c}\text { Molar ratio } \\
\text { (NP/HPßCD) }\end{array}$} & \multicolumn{3}{|c|}{$\begin{array}{c}\text { Molar ratio } \\
\text { (NP/Suc) }\end{array}$} & $\begin{array}{c}\text { PBS } \\
\left(\mathbf{m g} \cdot \mathbf{m L}^{-1}\right)\end{array}$ & $\begin{array}{c}\text { Molar ratio } \\
\text { (NP/PBS) }\end{array}$ \\
\hline 50 & $6.98 \mathrm{E}-04$ & & 200 & $4.28 \mathrm{E}-05$ & & 4.1 & $2.51 \mathrm{E}-03$ \\
\hline 25 & $1.40 \mathrm{E}-03$ & & 100 & $8.56 \mathrm{E}-05$ & & 2.1 & $4.89 \mathrm{E}-03$ \\
\hline 10 & $3.49 \mathrm{E}-03$ & & 50 & $1.71 \mathrm{E}-04$ & & 1.0 & $1.03 \mathrm{E}-02$ \\
\hline 5.00 & $6.98 \mathrm{E}-03$ & & 25 & $3.42 \mathrm{E}-04$ & & - & - \\
\hline 2.50 & $1.40 \mathrm{E}-02$ & & 2.5 & $3.42 \mathrm{E}-03$ & & - & - \\
\hline 1.88 & $1.86 \mathrm{E}-02$ & & - & - & & - & - \\
\hline 1.25 & $2.79 \mathrm{E}-02$ & & - & - & & - & - \\
\hline 0.63 & $5.54 \mathrm{E}-02$ & & - & - & & - & - \\
\hline $\begin{array}{l}\text { Glycerol (\% } \\
\text { v/v) }\end{array}$ & $\begin{array}{c}\text { Molar ratio } \\
\text { (NP/Gly) }\end{array}$ & & $\begin{array}{l}\text { ene glycol } \\
\% \mathrm{v} / \mathrm{v})\end{array}$ & $\begin{array}{c}\text { Molar ratio } \\
\text { (NP/EG) }\end{array}$ & Pol & $\begin{array}{l}\text { thylene glycol } \\
(\% \mathrm{v} / \mathrm{v})\end{array}$ & $\begin{array}{c}\text { Molar ratio } \\
\text { (NP/PEG) }\end{array}$ \\
\hline 0.50 & $9.14 \mathrm{E}-07$ & 0.50 & & $6.99 \mathrm{E}-07$ & 0.25 & & $1.33 \mathrm{E}-02$ \\
\hline 0.25 & $2.74 \mathrm{E}-06$ & 0.25 & & $2.10 \mathrm{E}-06$ & 0.10 & & $4.00 \mathrm{E}-02$ \\
\hline 0.10 & $8.22 \mathrm{E}-06$ & 0.10 & & $6.29 \mathrm{E}-06$ & 0.05 & & $8.44 \mathrm{E}-02$ \\
\hline 0.05 & $1.74 \mathrm{E}-05$ & 0.05 & & $1.33 \mathrm{E}-05$ & 0.01 & & 4.40E-01 \\
\hline 0.01 & $9.04 \mathrm{E}-05$ & 0.01 & & $6.92 \mathrm{E}-05$ & - & & - \\
\hline
\end{tabular}

2.2.8. Curcumin (CUR) nanoparticles loading 
First of all, $1.0 \mathrm{mg}$ of CUR was dissolved in $2 \mathrm{~mL}$ of the solvent THF / $\mathrm{H}_{2} \mathrm{O}[9: 1(\% \mathrm{w} / \mathrm{w})]$ and stirred for $2 \mathrm{~h}$. Solution was then added to a flask containing $1.0 \mathrm{mg}$ of $\mathrm{BCPs} \mathrm{MH}-b-\mathrm{PI}_{3.8 \mathrm{kDa}}$ and stirred for more $24 \mathrm{~h}$ so that nanoprecipitation (e.g.) was performed according to Scheme 1. Amount of CUR loaded into NPs, and entrapment efficiency were indirectly estimated by UV-Vis measures, considering the Lambert-Beer's law.

To determine molar absorptivity $(\varepsilon)$ of the CUR in the solvent $\mathrm{THF} / \mathrm{H}_{2} \mathrm{O}[9: 1(\% w / w)]$, it was prepared a $10 \mu \mathrm{g} \cdot \mathrm{mL}^{-1}$ or $2.7 \times 10^{-5} \mathrm{~mol} . \mathrm{L}^{-1}$ solution. This solution was stirred by $1.5 \mathrm{~h}$ to guarantee the good homogenization of the system. In a quartz cuvette fulfilled with $2 \mathrm{~mL}$ of solvent $\mathrm{THF} / \mathrm{H}_{2} \mathrm{O}[9: 1(\% \mathrm{w} / \mathrm{w})]$, aliquots of $100 \mu \mathrm{L}$ of the CUR solution were added and the spectra obtained for each in a UV-Vis spectrophotometer Varian Cary-60. An absorbance vs concentration curve was built, where the angular coefficient was given as $\varepsilon$. The entrapment efficiency (\%) Eq. (4) was estimated as the difference between the total CUR concentration found in the NPs suspensions after completely dissolution in $\mathrm{THF} / \mathrm{H}_{2} \mathrm{O}$ [9:1 (\% w:w)] (CUR total), and total concentration of medicine in the supernatant obtained after centrifugation (10,000 rpm, $10 \mathrm{~min}, 298 \mathrm{~K}$ ) (CUR supernatant) $[\underline{40}, \underline{41}] .(4)$ Entrapment Efficiency\%= CURtotal-CURsupernatantCURtotal.100

\subsubsection{Characterization of loaded NPs}

DLS and TEM analysis were carried on CUR loaded NPs in order to assure the preservation of their properties and structure. Zeta Potential was determined using a Zetasizer Nano ZSP (Malvern Instruments, USA), adapting from Piai J.; 2008, and Camilo K. F. B.; 2007, procedures [42, $\underline{43}]$. NPs samples had their $\mathrm{pH}$ adjusted $(3,5,6.8,7.4$ and 9$)$ using sodium hydroxide $\left(\mathrm{NaOH}, 1.0 \mathrm{~mol}^{-\mathrm{L}^{-1}}\right)$ and acetic acid $\left(\mathrm{CH}_{3} \mathrm{COOH}, 0.5 \mathrm{~mol} . \mathrm{L}^{-1}\right)$, so that the final dispersions were $10 \times$ diluted in a $10 \mu \mathrm{M} \mathrm{NaCl}$ aqueous solution prepared with ultrapure Milli- $Q \circledR$ water, stirred during 10 min to reach the equilibrium and placed in an electrophoretic cell. The assay was performed in duplicate and zeta potential measures were considered the average between 3 determinations. This procedure was repeated without ionic force control using $\mathrm{NaCl}$. Besides that, zeta potential was measured in the NPs solution $(\mathrm{pH} 6,6)$ without any dilution, addition of water, acidic or basic solutions and salt.

\subsubsection{Stability of CUR-charged NPs}

CUR-charged NPs solution ( $\mathrm{pH}$ 6.6) was stocked in freezer (277 K) during 23 days to check its stability, and analysed by UV-Vis with a Varian Cary-60 spectrophotometer and by fluorescence emission with a Varian Cary-Eclipse apparatus. An amount of the same solution was incubated in SGF ( $\mathrm{pH} 1.2)$ and SIF ( $\mathrm{pH} 6.8)$, kept at the same place (20 days) and analysed as well. To verify any changes in NPs stability into body conditions, a dissolution bath (Ethik Technology, model 299-6TS, Brazil) was used in order to maintain controlled temperature. NPs solution was split into 13 Eppendorf 
tubes (500 $\mu \mathrm{L}$ each $+500 \mu \mathrm{L}$ of SGF or SIF) so that the tubes were kept at a thermostatic water bath set at $309.5 \mathrm{~K}$ and $50 \mathrm{rpm}$. At predetermined time intervals, the absorbance and fluorescence emission intensities of the suspensions were monitored.

\subsubsection{Cytotoxic analysis}

Several tumoral (Caco-2, PC3, Hela, SiHa and C33) and healthy (HaCat, Vero and fibroblasts L929) cell lines were tested by colorimetric MTT assay, to access cytotoxic evaluation. This method is based on the capacity of available mitochondria to convert MTT, a tetrazolium salt (3-(4,5-dimethylthiazol2yl)-2,5-diphenyl tetrazolium bromide) in dark blue formazan crystals [44]. A suspension of cells (phase log of growth), in a concentration of $2.5 \times 10^{5}$ cells. $\mathrm{mL}^{-1}$ in culture medium RPMI 1640 (for PC3 cells) or DMEM (for all others cell lines) supplemented with $10 \%$ of foetal bovine serum (FBS), was dispensed in sterile plates containing 96 wells each and incubated at $310 \mathrm{~K}$ for $24 \mathrm{~h}$ and $5 \%$ of $\mathrm{CO}_{2}$ atmosphere. After this period, the supernatant was removed and aliquots with different concentrations of the studied substance were added to the media.

Succeeding $48 \mathrm{~h}$ of incubation in the same conditions, as previously cited, the cells from all wells were washed with PBS $0.01 \mathrm{M}$ and $50 \mu \mathrm{L}$ of MTT $\left(2 \mathrm{mg} \cdot \mathrm{mL}^{-1}\right)$ and incubated in absence of light, at $298 \mathrm{~K}$. Four hours later, $150 \mu \mathrm{L}$ of DMSO were added in order to break up the cells and solubilize the formazan crystals produced. Absorbance was acquired through a spectrophotometer (BIO-TEK Power Wave XS spectrophotometer) at $570 \mathrm{~nm}$. Values of $\mathrm{CC}_{50}$ (cytotoxic concentration of $50 \%$ ) were determined and compared to the control values. All the assays were carried in triplicates $(n=3)$.

\section{Results and discussion}

\subsection{SLS to determination of solvent optimal conditions}

Before preparing NPs, it was necessary to define the best solvent to well solubilize BCP chains so that they are as free as possible. In this case, the best solvent comes from a mixture between two miscible solvents, a hydrophilic and a hydrophobic, besides the percentage between them changes according to the amphiphilic character of the BCP. S. Kim and J. Xu, for example, monitored the $R_{h}$ of amine molecules derived from maize and showed that their degree of aggregation varies according to the percentage of each solvent, polar and nonpolar, that composes the mixture [45]. In many works, SLS was used and solvents were chosen because they had good refraction index values that, as combined, help on the reduction of the light scattering intensity beyond being good solvents to the respective systems $[\underline{46}, \underline{47}]$. Knowing that $\mathrm{MH}$ is a carbohydrate that could solubilize into water, THF [a cyclic ether from nucleophilic nature, applied in several industries and totally miscible in water] [48], was defined as a 
good organic solvent to PI units. SLS measurements were performed in all BCPs solutions at different proportions THF / water (from 0 to $100 \mathrm{wt}$ \%) and the obtained values were applied to Eq. (1) to build a curve (Fig. 1) that take into account $I_{\text {real }} \log v s$ wt-\% of solvent. It was of our interest to show the curve in the region about 70 to $100 \%$ of THF.

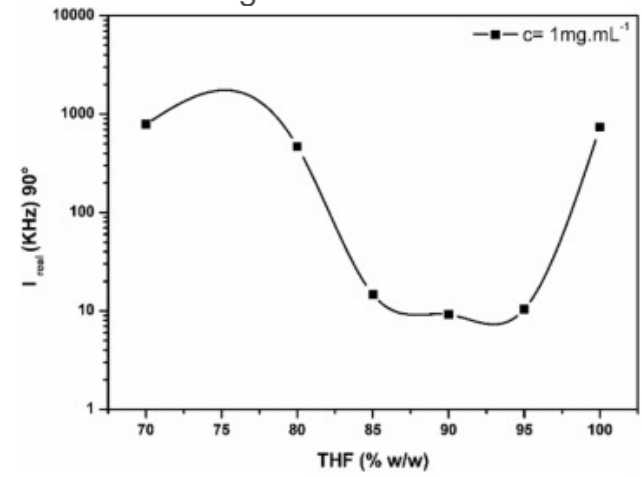

Fig. 1. Real light intensity as a function of THF fraction for a polymeric solution in a concentration of $1 \mathrm{mg} \cdot \mathrm{mL}^{-1}$. Measurements at $90^{\circ}$ and at normal conditions of $\mathrm{P}$ and $\mathrm{T}$.

The point at minimal intensity [9:1 (w:w) THF/water] indicates the best solvent ratio that well solubilize the $\mathrm{MH}-b-\mathrm{PI}_{3.8 \mathrm{kDa}} \mathrm{BCPs}$. In other words, at this point the polymeric chains seems to be individual, avoiding as far as possible aggregates, and up to self-organize in NPs according to the proposed methodology.

\subsection{DLS measurements}

DLS provides information about particles in a size range from few nanometers to $5 \mu \mathrm{m}$, besides that, this method uses techniques of optical mixtures and correlation analysis to obtain the translational diffusion coefficients (Brownian) from the particles [49]. NPs $R_{h}$ was obtained from the diffusion coefficient $(D)$, acquired by the slope of the plot of relaxation frequency $(1 / \tau)$ versus squared wave vector modulus $\left(q^{2}\right)$ (Fig. 2.a), using the Stokes-Einstein relation.
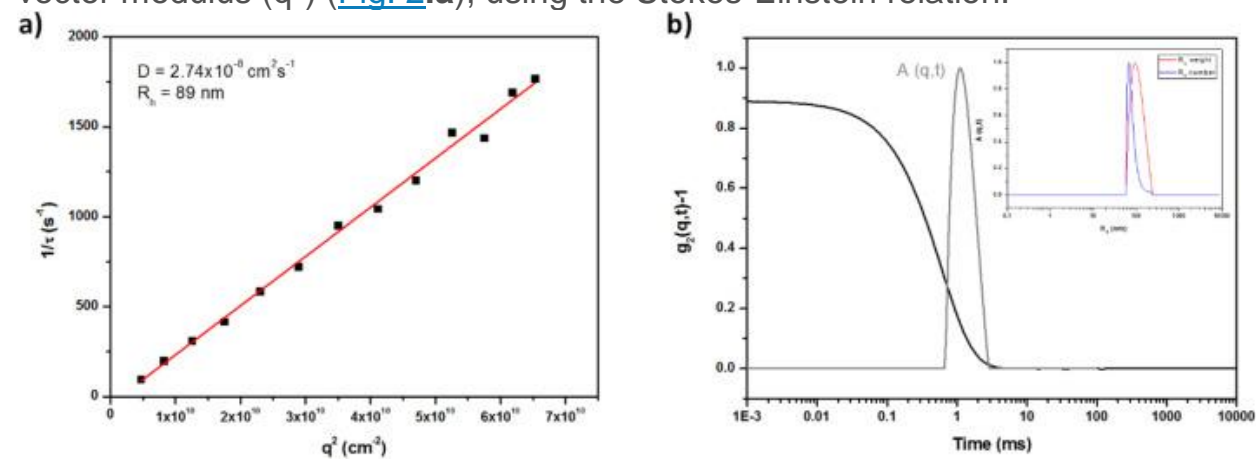

Fig. 2. a) Dependence of the relaxation frequency $(1 / T)$ on the square of the wave vector modulus $\left(\mathrm{q}^{2}\right)$ of the aqueous suspensions of $\mathrm{MH}-b-\mathrm{PI}_{3.8 \mathrm{kDa}} \mathrm{NPs}$ and $\mathbf{b}$ ) correlation function $\left[g^{2}(q, t)-1\right]$ and decay time distribution. Inset shows the distribution of $R_{h}[A(q, t)]$ weight $\left(R_{h} W=94 \mathrm{~nm}\right)$ and number $\left(R_{h} N .=68 \mathrm{~nm}\right)$. (Scattering angle of $\left.90^{\circ}\right)$. 
In this work, a suspension with both blurred and homogeneous aspect was obtained after nanoprecipitation, confirming the NPs as being well dispersed in the medium.

DLS analysis showed that NPs presented monomodal distribution, being the average $R_{h}$ value $89 \mathrm{~nm}$, considering measurements in angles from 150 to $30^{\circ}$, this value was very close to $94 \mathrm{~nm}$ (Fig. 2.b) obtained at a fixed of angle of $90^{\circ}$. In the second case, correlation function and $R_{h}$ distribution in weight $\left(R_{h}\right.$ W. $)$ and in number $\left(R_{h}\right.$ N.) are illustrated as two curves (Fig. 2.b, inset graph) which furnish values of diameter, $136 \mathrm{~nm}\left(R_{h} N .=68 \mathrm{~nm}\right)$ and $188 \mathrm{~nm}\left(R_{h} W .=94 \mathrm{~nm}\right)$, according to the mode of calculation.

In the case of medicines encapsulation for therapeutic purpose, NPs smaller than $200 \mathrm{~nm}$ have the potential of permeation and diffusion between a great sort of tissues, so it can bond themselves to receptors in the cells surfaces and be internalized by the compartments to intracellular delivering of drugs [50]. Thus, $\mathrm{MH}-b-\mathrm{PI}_{3.8 \mathrm{kDa}} \mathrm{NPs}$ possess characteristics as chemical (biological compatibility and biodegradability) as physical (nanometric dimensions) which enhance their use as drug carriers to the treatment of several pathologies. These characteristics are auspicious when leading with different types of medicines, which do not have a great ability to be transported directly by the blood system.

\subsection{Nanoparticle Tracking Analysis (NTA) measurements}

NTA is a relatively new technique to characterize particles in nanoscale. NTA could be applied to determine size and concentration of cellular vesicles because the method offers distinctly advantages when compared to others. It is faster than TEM and AFM allowing analysis of large amount of vesicle samples and, as they are analysed in solution, they are not subjected to contraction [33]. NTA endorses results from DLS because the technique is similar to the light scattering and furnishes the NPs diameter $\left(R_{h} N\right.$.).

Comparing NTA and DLS to protein analysis, in general the obtained results were similar [51]. NTA is an accurate method to size determination as well as in monodisperse than in polydisperse models. It presents a well peak resolution and even if there are some big particles in the solution medium, they show a small impact above the precision in the size measurement, although it reduces the number of small particles detected by the equipment $[32, \underline{52}]$.

Fig. 3 displays NPs diameter distribution shaped after video recording analysis. Considering three videos recorded consecutively, the predicted diameter value is $131.6 \mathrm{~nm}$ to NPs obtained from MH- $b$ $\mathrm{PI}_{3.8 \mathrm{kDa}} \mathrm{BCPs}$. This result is shortly smaller than those obtained by DLS $\left(\mathrm{R}_{\mathrm{h}} \mathrm{N} .=136 \mathrm{~nm}\right)$ and few more distant from those results obtained considering the weight $\left(R_{h} W=188 \mathrm{~nm}\right)$ of the largest NPs. Occasionally, average diameters obtained by NTA analysis can remain succinctly smaller than those obtained by DLS. In the case of the distribution by DLS, this difference can be justified in terms of 
weight, whilst NTA measurements are always obtained considering the total number of particles in the sample [32].

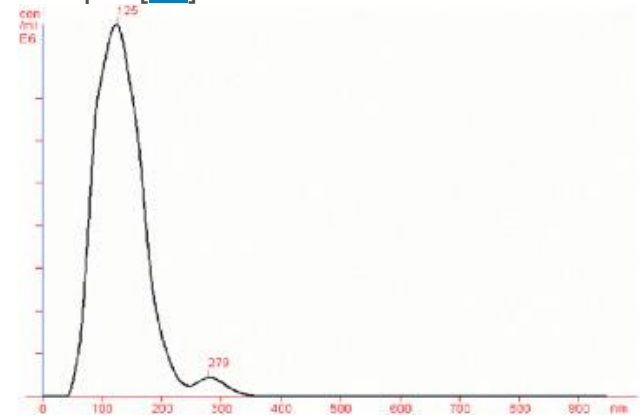

Fig. 3. Size distribution graph obtained after NTA video frame analysis of $\mathrm{MH}-b-\mathrm{PI}_{3.8 \mathrm{kDa}} \mathrm{NPs}$. A difference on the average diameter values given by NTA and by DLS, must be due the fact that distributions obtained by DLS are bigger, once this technique considers the contribution from the fraction of largest particles population [53].

In our work, the equipment used to perform DLS analysis possesses a specific software, which was able to give results in terms of number distribution $\left(R_{h} N\right.$.). Thus, the values obtained by both techniques seemed to be very close. This evidences that NTA must substitute or be applied in combination to DLS to furnish information about NPs size, to once more, show that NPs produced in this work are promising to be used as anticancer agents.

\subsection{TEM observations}

Fig. 4a) presents TEM images that reveal the success in the formation of spherical NPs with average diameter of $123 \pm 23 \mathrm{~nm}(n=33)$, besides the dimensions are coherent with the results from DLS and NTA.

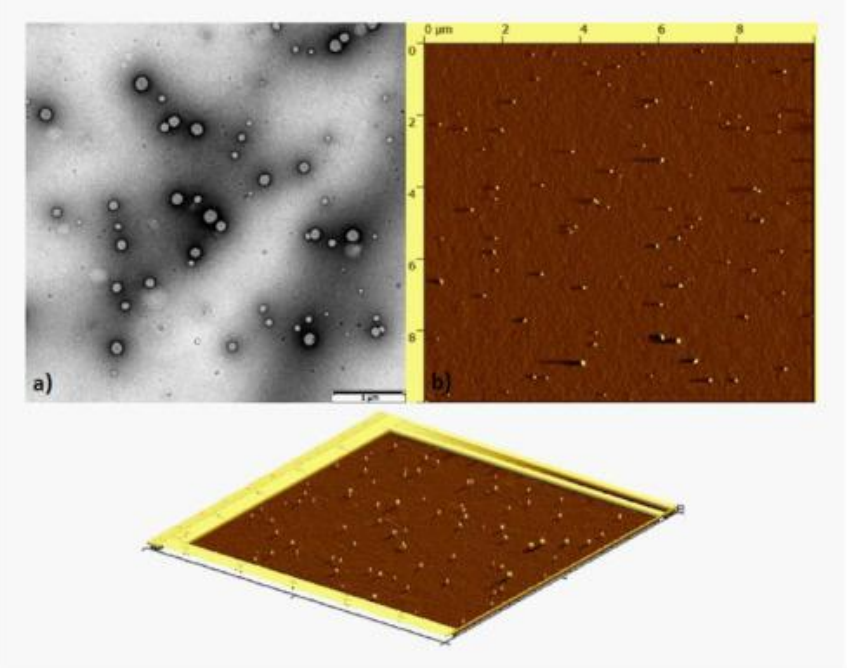

Fig. 4. a) TEM and b) AFM with 3D view (bottom) images from glyco-NPs, obtained through $\mathrm{MH}-b-\mathrm{Pl}_{3.8 \mathrm{kDa}}$ self-assembly in water. 
DLS is based in a principle which provides the average diameter of the NPs while TEM reveals the individual diameters [54]. Absence of large micellar aggregates in the images evidenced NPs with monomodal distribution, as highlighted on DLS and NTA discussions and reinforce this statement. Spherical silhouette was verified, and a slightly presence of inhomogeneity in the NPs surfaces shall be occasioned due formation of bowl-shaped regions.

\subsection{AFM observations}

AFM technique has been used in several works involving NPs for determination of their morphology, size and interactions $[\underline{55}, \underline{56}]$. Besides that, sample preparation is very important, to the quality of results.

Spin coating was the best technique to deposit MH- $b-\mathrm{PI}_{3.8 \mathrm{kDa}} \mathrm{NPs}$ in Si surfaces, comparing to natural drying. Fig. 4.b shows a monodisperse size distribution displaying a spheroid shape with an average diameter of $129 \pm 30 \mathrm{~nm}(n=90)$. These data are consistent with those obtained by TEM $(123 \pm 23 \mathrm{~nm})$. NPs diameters defined in this work have consistent values in comparison with those found in the literature, so that the range of possibilities for application of the newest structures, presented here, increases. Diameters obtained by AFM image analysis are very close to the ones found by TEM. Deposition and drying processes must express such values.

Differences in NPs sizes obtained by DLS and NTA against those from TEM and AFM correspond to the fact that TEM and AFM show the NPs morphology in solid state. Therefore, the results must suffer some influence by agglomeration effects and/or flattening, while DLS and NTA give hydrodynamic diameter in aqueous solutions, considering solvation layer and a radius of hydration.

\subsection{Nanoparticles lyophilisation}

Lyophilisation rises colloidal NPs stability, once they cannot be enough durable in aqueous media and it is a serious drawback with respect to clinical use of NPs [ $[\underline{36}, \underline{57}]$. It consists in a dehydration process, based in three steps, freezing, first drying and second drying. Besides improvement on suspensions stability, lyophilisation simplify their manipulation and stockage [ [58].

A well-lyophilized material shall preserve characteristics from the initial product which are indispensable. For example, physical-chemistry properties, size distribution, and also show aptitude to form a good aspect system which can be easily reconstituted and comprise a low moisture rate [59]. After lyophilized with different substances, the samples from this work were reconstituted with ultrapure water and their aspect analysed by DLS (ig. 5 ). 


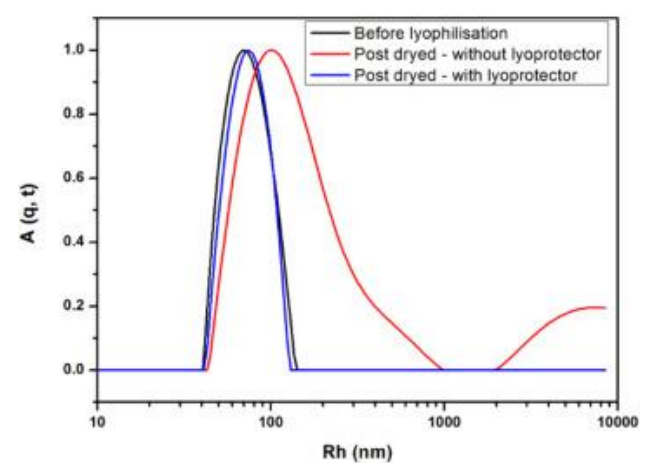

Fig. 5. DLS representation of three stages of a NPs solution: before lyophilisation (black); after lyophilisation without addition of a lyoprotector (red); and after lyophilisation with addition of a lyoprotector (blue).

Effectiveness of the lyoprotection to the NPs suspensions was measured through the relation $S_{f} / S_{i}$. The closer $S_{f} / S_{i}$ ratio to 1 the more efficient is the lyoprotector [38] because it allows best efficacy on rehydration process [35]. Values $S_{f} / S_{i}$ for all lyoprotectors were displayed on Fig. 6 and Table 2 , and evidenced that 2-hydroxypropyl- $\beta$-cyclodextrin (HPBCD) in a concentration of $2.5 \mathrm{mg}^{-1} \mathrm{~mL}^{-1}$ was the best lyoprotectant for $\mathrm{MH}-b-\mathrm{PI}_{3.8 \mathrm{kDa}} \mathrm{NPs}$ with a $\mathrm{S}_{\mathrm{f}} / \mathrm{S}_{\mathrm{i}}$ value of 1.0)
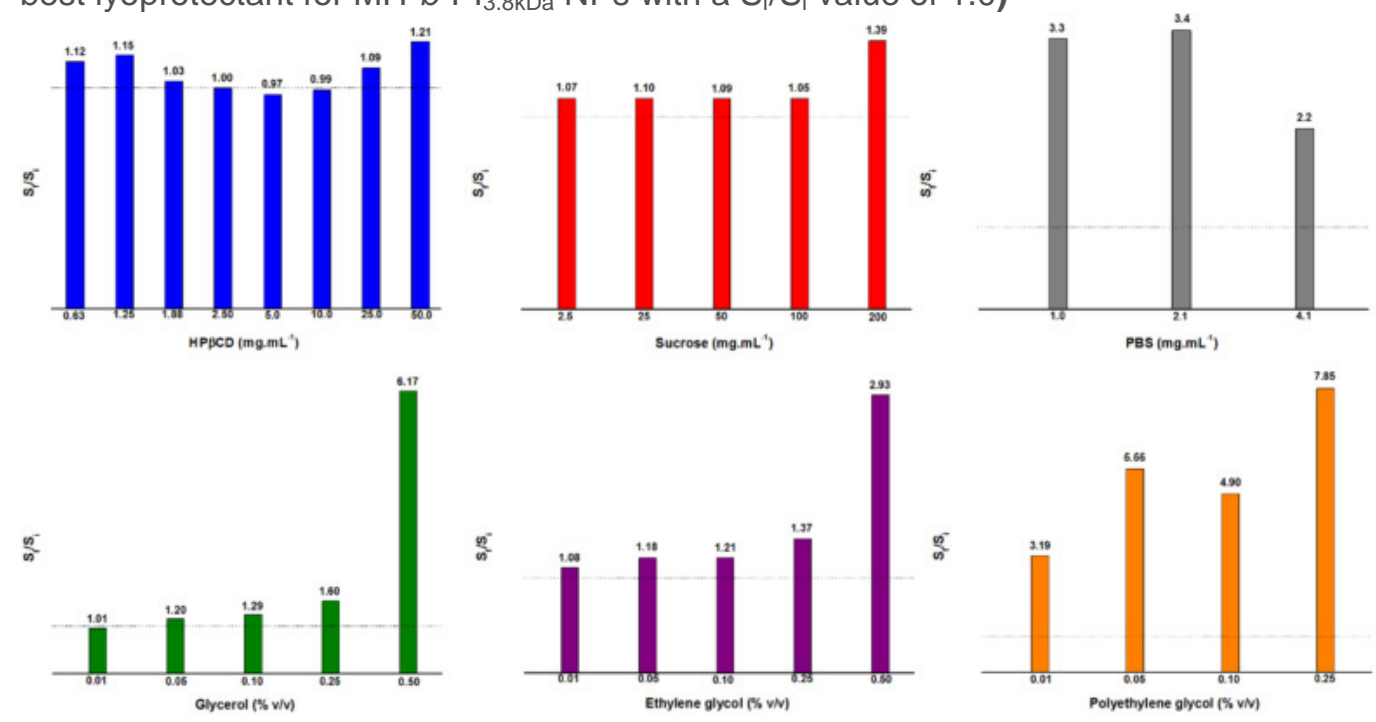

Fig. 6. $\mathrm{S}_{\mathrm{f}} / \mathrm{S}_{\mathrm{i}}$ ratio for all lyoprotectors applied on $\mathrm{MH}-b-\mathrm{PI}_{3.8 \mathrm{kDa}} \mathrm{NPs}$. Dot lines show the region where the $S_{f} / S_{i}$ ratio is equal to 1.00 .

Table 2. Concentration and $\mathrm{S}_{\mathrm{f}} / \mathrm{S}_{\mathrm{i}}$ ratio with standard deviation (SD) for all substances tested as lyoprotectors to freeze drying of $\mathrm{MH}-b-\mathrm{PI}_{3.8 \mathrm{kDa}} \mathrm{NPs}$.

\begin{tabular}{|c|c|c|c|c|c|c|c|c|}
\hline $\mathrm{HP \beta CD}\left(\mathrm{mg} \cdot \mathrm{mL}^{-1}\right)$ & $\mathbf{S}_{\mathrm{f}} / \mathbf{S}_{\mathrm{i}}$ & SD & Sucrose $\left(\mathrm{mg} \cdot \mathrm{mL}^{-1}\right)$ & $\mathbf{S}_{\mathrm{f}} / \mathbf{S}_{\mathrm{i}}$ & SD & PBS (mg.mL $\left.{ }^{-1}\right)$ & $\mathbf{S}_{\mathrm{f}} / \mathbf{S}_{\mathrm{i}}$ & SD \\
\hline 50 & 1.21 & 6.50 & 200 & 1.39 & 1.76 & 4.1 & 2.20 & 63.6 \\
\hline 25 & 1.09 & 2.30 & 100 & 1.05 & 4.25 & 2.1 & 3.40 & 93.1 \\
\hline 10 & 0.99 & 3.69 & 50 & 1.09 & 3.55 & 1.0 & 3.30 & 27.5 \\
\hline 5.00 & 0.97 & 3.02 & 25 & 1.10 & 3.54 & - & - & - \\
\hline 2.50 & 1.00 & 1.34 & 2.5 & 1.07 & 3.15 & - & - & - \\
\hline 1.88 & 1.03 & 1.61 & - & - & - & - & - & - \\
\hline 1.25 & 1.15 & 3.94 & - & - & - & - & - & - \\
\hline
\end{tabular}




\begin{tabular}{|c|c|c|c|c|c|c|c|c|}
\hline HPßCD (mg.mL $\left.{ }^{-1}\right)$ & $\mathbf{S}_{\mathrm{f}} / \mathbf{S}_{\mathrm{i}}$ & SD & Sucrose $\left(\mathrm{mg} \cdot \mathrm{mL}^{-1}\right)$ & $\mathbf{S}_{\mathrm{f}} / \mathbf{S}_{\mathrm{i}}$ & SD & PBS (mg.mL $\left.{ }^{-1}\right)$ & $\mathbf{S}_{\mathrm{f}} / \mathbf{S}_{\mathrm{i}}$ & SD \\
\hline 0.63 & 1.12 & 3.85 & - & - & - & - & - & - \\
\hline
\end{tabular}

\begin{tabular}{lllllllll} 
Glycerol (\% v/v) & $\mathbf{S}_{\mathbf{f}} / \mathbf{S}_{\mathbf{i}}$ & $\mathbf{S D}$ & Ethylene glycol $(\% \mathbf{v} / \mathbf{v})$ & $\mathbf{S}_{\mathbf{f}} / \mathbf{S}_{\mathbf{i}}$ & $\mathbf{S D}$ & Polyethylene glycol $(\% \mathbf{v} / \mathbf{v})$ & $\mathbf{S}_{\mathbf{f}} / \mathbf{S}_{\mathbf{i}}$ & $\mathbf{S D}$ \\
\hline 0.50 & 6.17 & 27.56 & 0.50 & 2.93 & 6.44 & 0.25 & 7.85 & 160.2 \\
0.25 & 1.60 & 3.78 & 0.25 & 1.37 & 3.87 & 0.10 & 4.90 & 102.2 \\
0.10 & 1.29 & 1.89 & 0.10 & 1.21 & 5.49 & 0.05 & 5.56 & 158.4 \\
0.05 & 1.20 & 6.80 & 0.05 & 1.18 & 3.42 & 0.01 & 3.19 & 113.8 \\
0.01 & 1.01 & 2.24 & 0.01 & 1.08 & 8.91 & - & - & -
\end{tabular}

HP $\beta C D$ has been capable to preserve NPs morphological characteristics during and after lyophilisation process. With values of $S_{\mathfrak{f}} / S_{i}$ below and above 1.0, the system must destabilize causing variation in the NPs diameter.

Second criteria besides the relation $S_{\mathcal{F}} / S_{i}$ that provides the evaluation of the protective effect of substances is based on the clarity of disperse suspensions. Transparence influences in the media because when solutions contain agglomerated particles, these ones precipitate and cannot be seen by DLS [39].

Addition of HPBCD on NPs system before the lyophilisation process allows total and instantaneous reconstitution of the product, dispensing mechanical shaking or sonication after the process. Other substances tested as lyoprotectors (PBS, glycerol, ethylene glycol, polyethylene glycol), provide post lyophilisation NPs- $R_{h}$ values different from those before lyophilisation or even with precipitated particles being visible to the naked eye.

$\mathrm{HP} \beta C D$ is better in terms of lyoprotection when compared to the other studied substances and this must be related to its non-crystalline nature, besides that, it possesses a relatively high $T_{g}$, when compared to the other ones. Thus, HPBCD preserved the system integrity and prevented the NPs from aggregation [39]. HPBCD increased the NPs stability after lyophilization and behaved as lyoprotector hindering the rupture of the micelles when exposed to low temperatures. It is very useful because when found in solid state NPs are better conserved and transported. Moreover, after be suspended in water, $\mathrm{MH}-b-\mathrm{PI}_{3.8 \mathrm{kDa}} \mathrm{NPs}$ kept their initial characteristics.

\subsection{Nanoparticles loading with Curcumin (CUR)}

DLS analysis of CUR-loaded NPs revealed a $R_{h} N$. of $89 \mathrm{~nm}(d=180 \mathrm{~nm})$ and one of the main evidences that shows CUR entrapment by NPs refers to the difference in the colour of aqueous media when NPs are present and when they are not. Fig. 7.a represents two samples submitted to nanoprecipitation. On the left there is a flask containing NPs charged with CUR (intense yellow) and on the right, a flask with CUR (without NPs) that was poorly solubilized in water, presenting a feeble yellow coloration. 

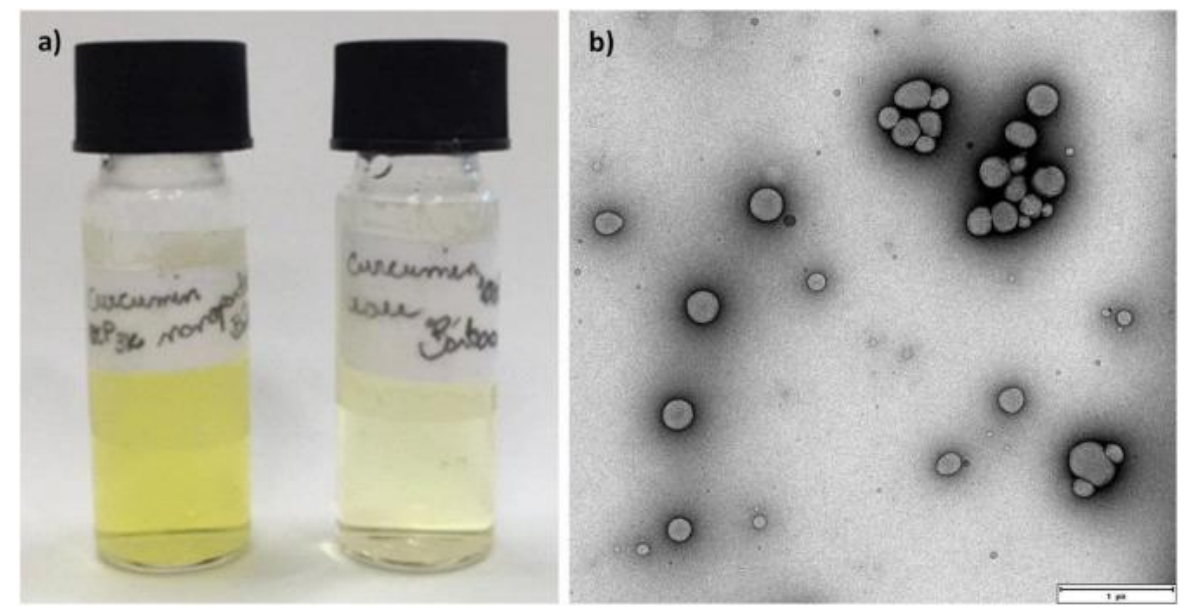

Fig. 7. a) Nanoprecipitation effect to $\mathrm{MH}-b-\mathrm{Pl}_{3.8 \mathrm{kDa}}+\mathrm{CUR}$ (left) and to water + CUR (right) and b) TEM image of CUR loaded MH- $b-\mathrm{PI}_{3.8 \mathrm{kDa}} \mathrm{NPs}$.

TEM results exhibited spheroid NPs even after CUR entrapment (Fig. 7.b), with a number average diameter of $195 \pm 62 \mathrm{~nm}(n=33)$, data corresponds with the value furnished by DLS. The morphology did not change significantly after entrapment of CUR. CUR must interact with the both regions of the NPs, the core and the shell, once its structure has a polar and nonpolar portion.

Interaction studies on NPs with cell membranes are extremely important. Lipid transport, proteins, glucose and other biomaterials interface as well as by exocytic and endocytic ways. NPs ability of penetration into the cells must be considered at the moment of their design [ㅁ]. In a scale small than $200 \mathrm{~nm}$ intravascular injection of NPs charged with medicines becomes available without concern embolization. They have a potential to permeate and to circulate through different tissues, being able to connect in cell surface receptors, to be internalized into target cells to distribution of drugs and to influence the ways of intracellular segment [50]. Once more, the analysis show that CUR-charged NPs have a great role when concerning drug treatments and releasing, as the polymers used to build the NPs are biocompatible as well as the medicine.

\subsection{Entrapment efficiency of CUR-charged nanoparticles}

A curve from absorption vs. wavelength was built to a CUR solution prepared in $\mathrm{THF} / \mathrm{H}_{2} \mathrm{O}$ [9:1 $(\% \mathrm{w} / \mathrm{w})$ ], varying from $1.04 \times 10^{-6} \mathrm{~mol} . \mathrm{L}^{-1}$ to $1.24 \times 10^{-5} \mathrm{~mol} . \mathrm{L}^{-1}$, obtained from dilution of a stock solution $\left(0.027 \times 10^{-3} \mathrm{~mol}^{-1} \mathrm{~L}^{-1}\right)$ (Fig. 8.a). A straight curve with an angular coefficient of $70,686.7 \mathrm{~L} \cdot \mathrm{mol}^{-1} \cdot \mathrm{cm}^{-1}$, from absorption vs CUR concentration (maximum wavelength) was obtained, characterizing the molar absorptivity of CUR (Fig. 8.b). 

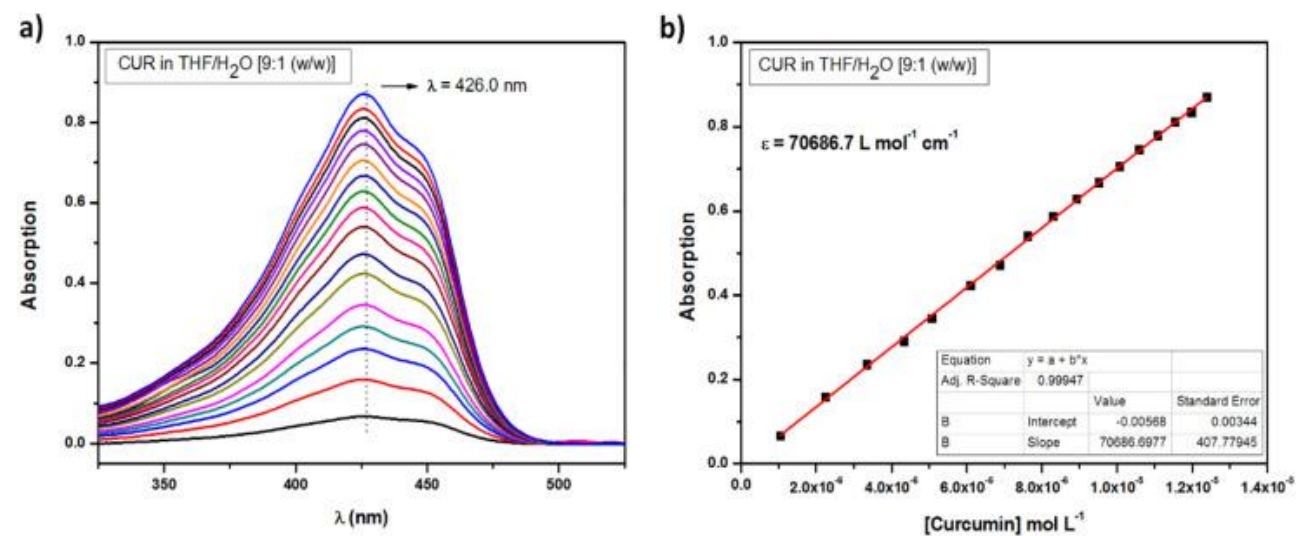

Fig. 8. a) Absorption vs Wavelength curve of CUR solutions, ranging from $1.04 \times 10^{-6} \mathrm{~mol} . \mathrm{L}^{-1}$ to $1.24 \times 10^{-5} \mathrm{~mol} . \mathrm{L}^{-1}$ and b) Absorption vs Curcumin concentration. Both a) and b) plots were obtained from data at fixed $\mathrm{THF} / \mathrm{H}_{2} \mathrm{O}$ ratio $[9: 1(\% \mathrm{w} / \mathrm{w})]$.

Concentration of CUR in the NPs suspensions was estimated obtaining the absorption value for each bath of solution, before and after centrifugation so that, applying to Eq. (4), the average value was $1.02 \times 10^{-6} \mathrm{~g} \cdot \mathrm{mL}^{-1}$ and entrapment efficiency, estimated from six CUR charged NPs batch, was predicted as being $70.5 \pm 10 \%$.

NPs presented good rate of CUR encapsulation, then they must be greatly useful in the treatment of diseases, like cancer.

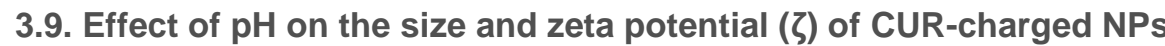

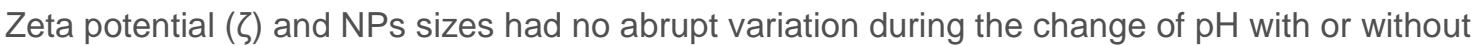
modifications in the ionic force $(\mu)$ by adding $\mathrm{NaCl}$. Fig. 9 indicates that the diameter was around $170 \mathrm{~nm}$ in all range of $\mathrm{pH}$ to NPs solution at constant $\mu$. At the same time, the values of $\zeta$ ranged from -3.6 to $-26.5 \mathrm{mV}$ as $\mu=10 \mu \mathrm{M}$. In absence of salt $\mathrm{NaCl}$, the $\zeta$ values ranged from -18.6 to $-38.9 \mathrm{mV}$. This behaviour matches with the non-ionic surfactant character of used BCPs, confirming their stability

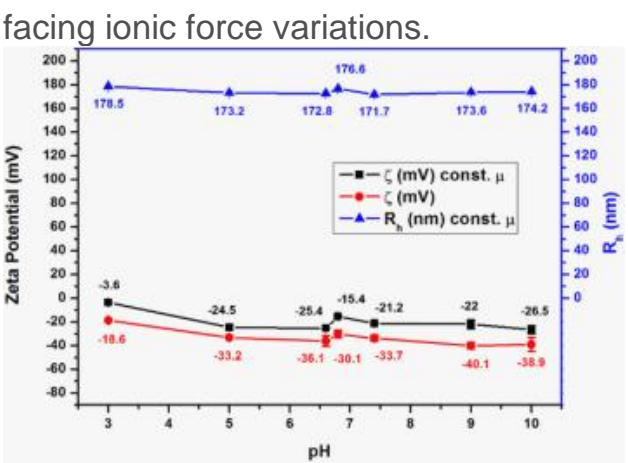

Fig. 9. Zeta potential $(\zeta, \mathrm{mV})$ and hydrodynamic radius $\left(\mathrm{R}_{\mathrm{h}}\right)$ of CUR-loaded nanoparticles as a function of $\mathrm{pH}$, in diluted $\mathrm{NaCl}$ solution (black, $\mu=10 \mu \mathrm{M}$ ) and in non-diluted solution (red).

The plot of $\zeta$ as a function of $\mathrm{pH}$ for CUR-loaded NPs shows a little increase in $\zeta$ values in acidic media $(\mathrm{pH}$ 3.0) for the both (with or without $\mathrm{NaCl}$ ), with values around -3.6 and $-18.6 \mathrm{mV}$ as compared to 
$\mathrm{pH}=6.6$, where $\zeta$ values were $-25.4 \mathrm{mV}$ (with $\mathrm{NaCl}$ present) and -36.1 (without $\mathrm{NaCl}$ ); and still to basic media ( $\mathrm{pH} 9.0$ and 10.0) where $\zeta$ presented almost the same values as in $\mathrm{pH} 6.6$.

An upturn in the zeta potential to highest values near acidic media can suggests the presence of protonated $-\mathrm{OH}$ groups in the structure of the polymer, more precisely in the $\mathrm{MH}$ region, which is a polyhydroxylated hydrophilic molecule, mostly or entirely found at the surface of the micelles (shell). Mazzarino L. and co-workers, for instance, observed increase in electrical charge at the surface of polycaprolactone NPs due to presence of positively charged amino groups [61]. To keep stable colloidal systems, inhibiting aggregation of particles, it is necessary values of zeta potential out of $\pm 30 \mathrm{mV}[\underline{39}]$ range. The NPs produced in this work possess $\zeta$ values that allow them to remain stable. Furthermore, $\zeta$ over the basic media denotes NPs very well stabilized once the values had not hugely changed.

To verify the initial NPs solution characteristic, $\zeta$ was also measured without any addition of water, acid or basic solutions, and the obtained value was $-36.1 \pm 3.3 \mathrm{mV}$ and the $R_{h}=176 \mathrm{~nm}$.

The shape of the NPs is nearly the same for both black and red $\zeta v s \mathrm{pH}$ curves in Fig. 9. The values of $\zeta$ obtained in absence of $\mathrm{NaCl}$ are more negative. This reinforces the evidence that NPs are more stable in a media with absence of salt.

\subsection{Stability of CUR-charged NPs}

Temporal stability of NPs in solution at pH 6.6 stored in freezer at $277 \mathrm{~K}$ during 23 days was evaluated by UV-Vis and fluorescence emission (Fig. 10.a). UV-Vis absorbance decreased gradually and was associated to CUR degradation. Instead of, the intensity of fluorescence emission increased from the day 1 to day 17 and finally decreases. Furthermore, a slightly delocalization in the maximal regions to low wavelengths, characterized a hypsochromic shift. This phenomena shall be due to the relocation of the CUR molecules, from the shell to the core into micelles, until the seventh day (increase in the fluorescence intensities), and after this period due to degradation which occurs at neutral-alkaline conditions [62]. 
a)
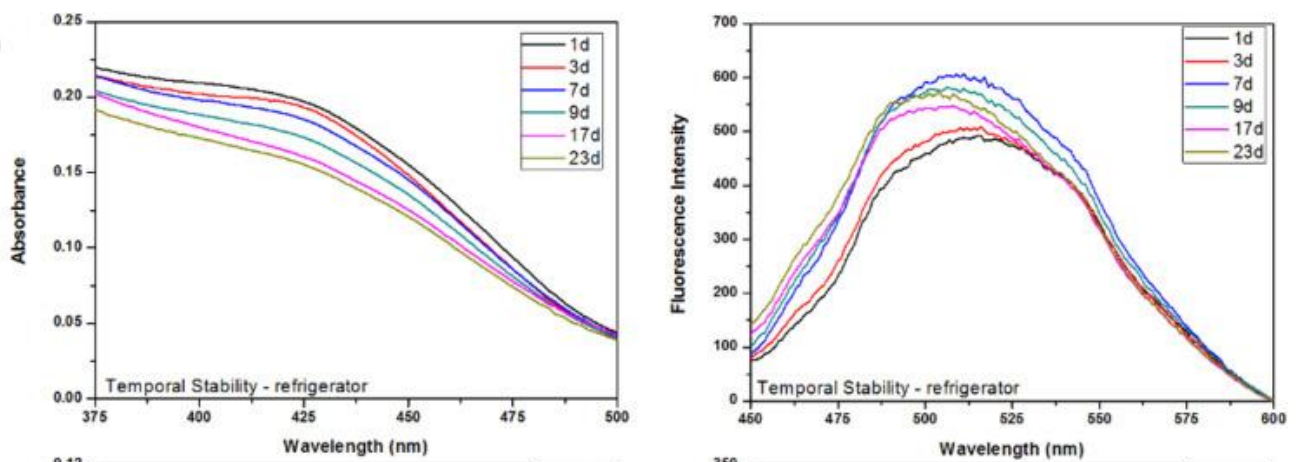

b)
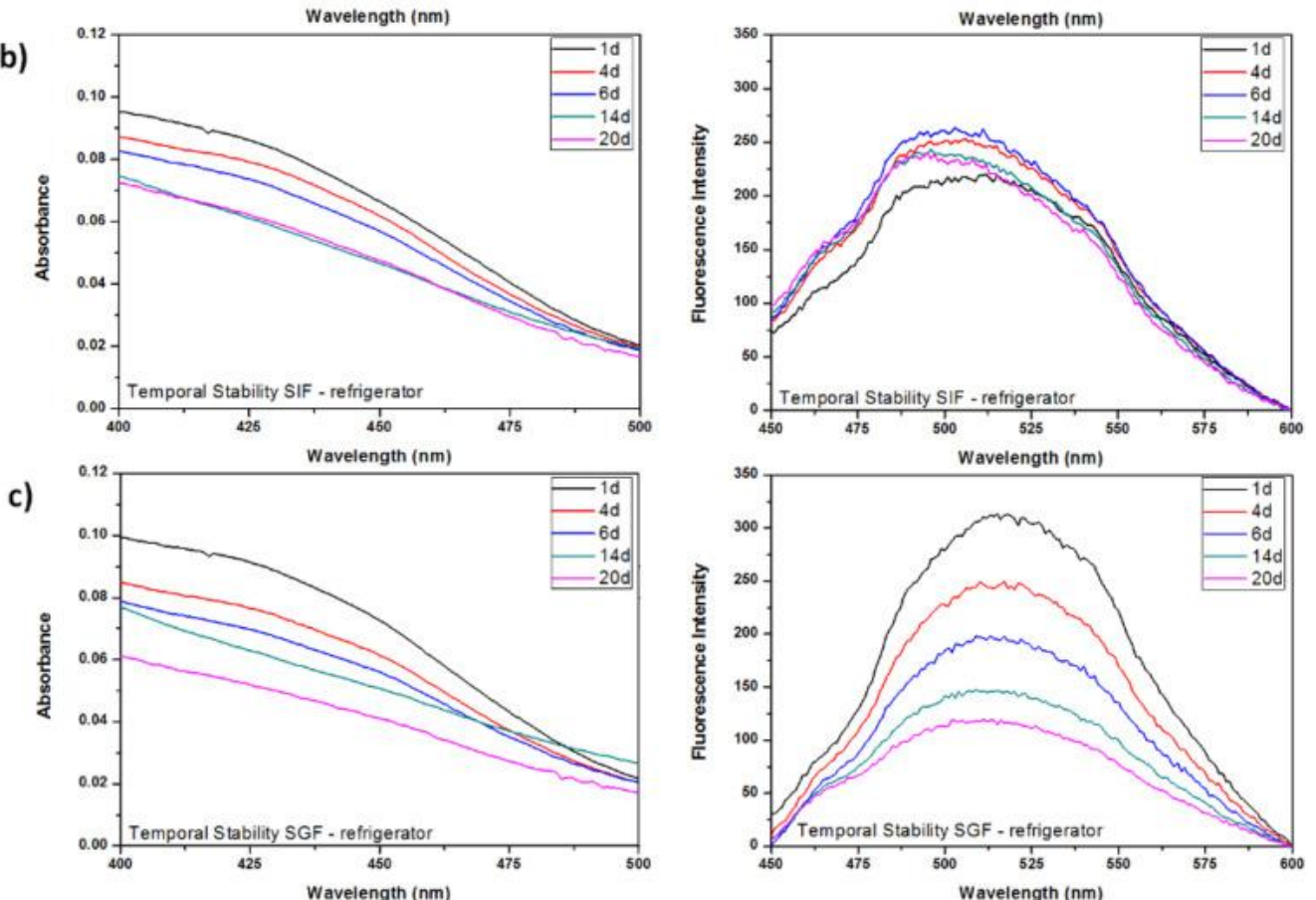

Fig. 10. Absorbance and fluorescence intensities vs wavelength for $\mathbf{a})$ NPs solution; $\boldsymbol{b})$ NPs solution in SIF; and c) NPs solution in SGF. All solutions were stocked in fridge at $277 \mathrm{~K}$.

The chemical structure of CUR changes depending on $\mathrm{pH}$ conditions assuming keto, enol or diketone conformation $[63,64]$. On the case of temporal stability of NPs stocked in the refrigerator into SIF (pH 6.8), the profile (Fig. 10.b) of the absorbance and fluorescence curves is very similar to the one presented to CUR-charged NPs solution in aqueous solution ( $\mathrm{pH}$ 6.6), suggesting a similar behaviour. On the other hand, when NPs are immersed in SGF (pH 1.2) the UV-Vis and fluorescence spectra (Fig. 10.c) converge in terms of lost in absorbance and fluorescence emission intensities. In other words, after the first day as one spectra as other presented gradual decrease in their intensities, representing CUR delocalization into the core of micelles, aggregation because CUR is more insoluble in acidic media [62] and/or even degradation [65] of CUR molecules.

NPs temporal stability on SIF and SGF dissolution bath, which simulates body conditions of temperature show equal UV-Vis profiles, presenting depletion in absorbance curves, progressively with the time. Otherwise, for fluorescence intensities, as well as in SIF and in SGF media, it was observed an increase in the emission intensity levels with a posterior decrease. 
Nonetheless, there is a maximum of intensity, but what really differs between them is the time that this phenomenon occurs. In SIF the maximal intensity occurs after $30 \mathrm{~min}$ and in SGF after $10 \mathrm{~min}$. Posteriorly, decrease in intensity is observed in both cases. Such behaviour represents a fast relocation and/or degradation of CUR inside of micelles, enabled particularly by the increase on the temperature.

When stability of CUR is verified in buffer solutions from $\mathrm{pH} 3$ to 10 , CUR degradation occurs after $30 \mathrm{~min}$ at neutral-basic conditions [65]. Even if a degradation occurs, CUR is stable for longer in serum and in blood [65]. Nevertheless, in the case of this work, CUR remains in a different system, what justifies its behaviour.

\subsection{Cytotoxic analysis}

Negative control represents the cells grown in their respective media without addition off any substance or NP. Non-loaded NPs, presented higher percentage of cell viability, for all cell lines.

Empty NPs showed no significant cytotoxicity against all cell lineages, so that, it is conclusive that NPs are non-toxic. Data represented by the second column of Table 3 'Cell viability for non-charged NPs' (first point section, Fig. 11).

Table 3. Cell viability for non-loaded CUR NPs, reduction in \% of cell growth with [CUR] and half-maximal inhibitory concentration of CUR $\left(\mathrm{IC}_{50}\right)$.

$\begin{array}{cccc}\begin{array}{c}\text { Cell } \\ \text { line }\end{array} & \begin{array}{c}\text { Cell viability for non- } \\ \text { charged NPs }\end{array} & \begin{array}{c}\text { Reduction in \% of cell growth with } \\ \text { CUR NPs }\end{array} & \begin{array}{c}\text { Half-maximal Inhibitory [CUR] } \\ \left(\text { IC }_{50}\right)\end{array}\end{array}$

$\begin{array}{llll}\text { Caco-2 }^{\mathrm{a}} & 95.7 \% \pm 2.1 & 94.6 \% \pm 0.9 \text { to } 13.4 \% \pm 1.0 & 4.8 \mu \mathrm{M} \pm 0.6 \\ \mathrm{PC}^{\mathrm{a}} & 90.2 \% \pm 1.6 & 91.7 \% \pm 1.5 \text { to } 10.9 \% \pm 0.2 & 6.9 \mu \mathrm{M} \pm 1.2 \\ \mathrm{HeLA}^{\mathrm{a}} & 88.9 \% \pm 3.1 & 87.4 \% \pm 0.2 \text { to } 13.1 \% \pm 2.2 & 9.3 \mu \mathrm{M} \pm 0.5 \\ \mathrm{SiHa}^{\mathrm{a}} & 91.4 \% \pm 0.6 & 89.2 \% \pm 1.9 \text { to } 13.8 \% \pm 0.4 & 9.8 \mu \mathrm{M} \pm 1.3 \\ \mathrm{C}^{\mathrm{a}}{ }^{\mathrm{a}} & 96.3 \% \pm 0.9 & 98.2 \% \pm 2.6 \text { to } 10.4 \% \pm 1.0 & 5.3 \mu \mathrm{M} \pm 1.1 \\ \mathrm{HaCat}^{\underline{\mathrm{b}}} & 94.6 \% \pm 3.6 & 92.8 \% \pm 4.9 \text { to } 78.0 \% \pm 5.2 & 7.2 \mu \mathrm{M} \pm 0.6 \\ \text { Vero }^{\underline{\mathrm{b}}} & 97.3 \% \pm 1.2 & 94.1 \% \pm 0.1 \text { to } 79.4 \% \pm 3.2 & 8.1 \mu \mathrm{M} \pm 1.9 \\ \text { L929 }^{\underline{b}} & 88.9 \% \pm 2.7 & 89.8 \% \pm 2.1 \text { to } 70.7 \% \pm 2.3 & 7.5 \mu \mathrm{M} \pm 1.4\end{array}$

a

Cancer cells.

b

Healthy cells. 


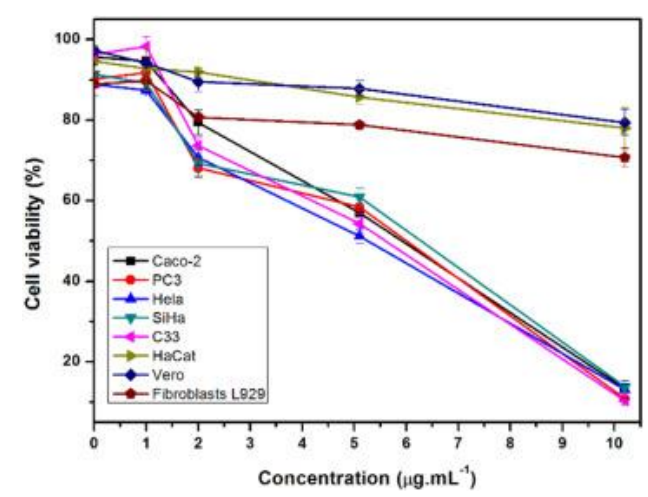

Fig. 11. Cytotoxicity effect of CUR-charged NPs on the viability of tumoral and healthy cell lines at different concentrations. Error bars represent the standard deviation of three measurements $(n=3)$.

CUR-loaded NPs incubated with tumoral and healthy cells at equivalent doses of 1.0, 2.0, 5.1 and $10.2 \mu \mathrm{g} \cdot \mathrm{mL}^{-1}$, respectively, had their cytotoxicity evaluated by MTT assay and the cell growth percentage was strongly reduced with the increase of drug concentration (second column, Table 3 , 'Cell growth \%') in the case of tumoral cells. Meanwhile the cell survival rate slightly changed with the increment of the drug concentration on the case of healthy cells.

All the cell lines were more sensitive towards positive control, CUR-charged NPs at concentrations above $1 \mu \mathrm{g} \cdot \mathrm{mL}^{-1}$ of CUR. All studied levels of CUR-charged NPs content into cell media demonstrated a concentration dependent cytotoxicity (Fig. 11). It proves that the active principle has a great role in wiping out unhealthy cells.

On behalf of this great results a well-entrapment effectiveness of CUR, could prevent side effects, such as toxicity in ordinary cells [5]. Half-maximum inhibitory concentration $\left(\mathrm{IC}_{50}\right.$, lethal concentration for $50 \%$ of cells) of CUR was smaller for Caco-2 and to C33 lines, in opposition to HeLA and SiHa, which presented the highest values (Table 3). In Fig. 12 the respective values are given also in $\mu g \cdot \mathrm{mL}^{-1}$ enabling the comparison with results of cell growth \% (Fig. 11).

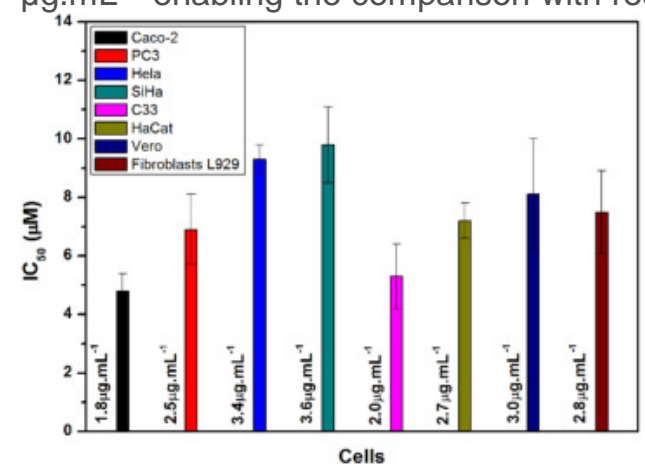

Fig. 12. Half-maximal $\left(I_{50}\right)$ inhibitory concentration of CUR in tumoral and healthy cell lines.

Error bars represent the standard deviation of three measurements $(n=3)$.

It is know that the drug availability is related to the solubility, diffusion and biodegradation of the matrix materials and also to the loading efficiency and size of the NPs [25]. The system, composed by CURloaded NPs formed by $\mathrm{MH}-b-\mathrm{PI}_{3.8 \mathrm{kDa}} \mathrm{BCPs}$, presented great assignment against tumoral cells. Looking 
at the values of cell viability in terms of NPs concentration, it is evident that CUR-loaded NPs are clearly capable to exterminate a huge amount of unhealthy cells and at the same time, there is no countless effect in destroying normal human keratinocytes cells, epithelial monkey cells and even fibroblasts mouse cells.

\section{Conclusions}

Original micelle NPs, composed by $\mathrm{MH}-b-\mathrm{PI}_{3.8 \mathrm{kDa}}$ blocks were successfully prepared through nanoprecipitation methodology. Self-assembly in water was a versatile method to entrap CUR with high efficiency and aiming NPs to drug release. The diameters of CUR-loaded NPs were enlarged because the presence of the drug and SLS was efficiently used to determine $\mathrm{THF} / \mathrm{H}_{2} \mathrm{O}$, in a proportion of 9:1 $(w / w)$, as the best solvent proportion to well solubilize the BCP chains. DLS assured a NPS $R_{h}$ of ca. $89 \mathrm{~nm}$ and NTA served as a complementary technique. TEM and AFM provided information about morphology. HPBCD was the best lyoprotectant among six analysed substances, enabling NPs to be very well resuspended in water after the drying process, maintaining their initial characteristics. NPs seemed to keep the $\mathrm{R}_{\mathrm{h}}$ relatively constant even with the changes in the $\mathrm{pH}$ values and zeta potential. NPs media has a representative stability once its zeta potential stays under $-30 \mathrm{mV}$. Stabilities of NPs in SIF and SGF were studied and it displayed that CUR may suffer by the effects of two phenomena, delocalization/aggregation into the micelles and degradation due to $\mathrm{pH}$ and temperature after a specific exposition time. Combination of carrier based on $\mathrm{MH}-b-\mathrm{Pl}_{3.8 \mathrm{kDa}} \mathrm{NPs}$ with the CUR as entrapped drug lead to a system with high cytotoxicity effects against tumoral cells but with minimal adverse effect on the viability of healthy cells. This work clearly proposes an innovative health care material designed to release a drug into unhealthy cells overcoming the barrier of solubility and distribution of the drug in the organisms. NPs developed here can serve as auspicious tools to application in further studies on cancer cells targeting.

\section{Author contributions}

This paper describes part of BSC's PhD Thesis, that was made under supervision of Prof. R. Borsali (in France) and of Prof. E. C. Muniz (in Brazil). All authors gave significant contributions to this paper. Also, after careful reading, all authors approved the final version of the manuscript.

\section{Credit authorship contribution statement}

Bárbara Sthéfani Caldas: Conceptualization, Methodology, Writing the draft. Danielle LazarinBidóia: Methodology. Celso Vataru Nakamura: Investigation. Sami Halila: Methodology. Redouane 
Borsali: Investigation, Writing - review \& editing. Edvani Curti Muniz: Supervision, Writing - review \& editing.

\section{Acknowledgments}

All authors would like to acknowledge institutions that sponsored this work, CNPq - Conselho Nacional

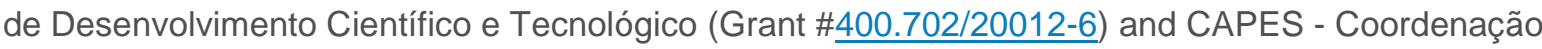
de Aperfeiçoamento de Pessoal de Nível Superior. Prof. Muniz thanks to CNPq (Grant \#150698/2018$\underline{6}$ and $\underline{307429 / 2018-0}$ ). This work has been partially supported by Polynat Carnot Institute (No. 16-

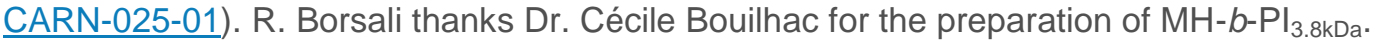

Appendix A. Supplementary data

Download : Download Word document (39KB)

Supplementary material

References

[1] G.-Y. Pan, H.-R. Jia, Y.-X. Zhu, F.-G. Wu, Turning double hydrophilic into amphiphilic: IR825conjugated polymeric nanomicelles for near-infrared fluorescence imagingguided photothermal cancer therapy, Nanoscale (2018) https://doi.org/10.1039/ C7NR07495F.

[2] A. Dev, A.K. Srivastava, S.R. Choudhury, S. Karmakar, Nano-curcumin influences blue light photodynamic therapy for restraining glioblastoma stem cells growth, RSC Adv. 6 (2016) 95165-95168, https://doi.org/10.1039/C6RA20269A.

[3] W.-D. Lu, Y. Qin, C. Yang, L. Li, Effect of curcumin on human colon cancer multidrug resistance in vitro and in vivo, Clinics 68 (2013) 694-701.

[4] M. Cui, et al., Multifunctional albumin nanoparticles as combination drug carriers for intraTumoral chemotherapy, Advanced Healthcare Materials 2 (2013) 1236-1245, https://doi.org/10.1002/adhm.201200467.

[5] J.H. Fang, et al., Magnetic Core-Shell Nanocapsules with dual-targeting capabilities and codelivery of multiple drugs to treat brain Gliomas, Advanced Healthcare Materials 3 (2014) 1250 1260, https://doi.org/10.1002/adhm.201300598.

[6] M. Vallet-Regí, E. Ruiz-Hernández, Bioceramics: from bone regeneration to cancer nanomedicine, Adv. Mater. 23 (2011) 5177-5218, https://doi.org/10.1002/adma. 201101586. 
[7] N. Bertrand, J. Wu, X. Xu, N. Kamaly, O.C. Farokhzad, Cancer nanotechnology: the impact of passive and active targeting in the era of modern cancer biology, Adv. Drug Deliv. Rev. 66 (2014) 2-25. https://doi.org/10.1016/j.addr.2013.11.009.

[8] A. Etxabide, V. Coma, P. Guerrero, C. Gardrat, K. de la Caba, Effect of cross-linking in surface properties and antioxidant activity of gelatin films incorporated with a curcumin derivative, Food Hydrocoll. 66 (2017) 168-175, https://doi.org/10.1016/j.foodhyd.2016.11.036.

[9] Bhawana, Basniwal, R. K., Buttar, H. S., Jain, V. K. \& Jain, N. Curcumin nanoparticles: preparation, characterization, and antimicrobial study. J. Agric. Food Chem. 59, 2056-2061, doi:https://doi.org/10.1021/jf104402t(2011).

[10] R.K. Singh, et al., Synthesis, antibacterial and antiviral properties of curcumin bioconjugates bearing dipeptide, fatty acids and folic acid, Eur. J. Med. Chem. 45 (2010) 10781086, https://doi.org/10.1016/j.ejmech.2009.12.002.

[11] X. Qiu, et al., Synthesis and identification of new 4-arylidene curcumin analogues as potential anticancer agents targeting nuclear factor-KB signaling pathway, J. Med. Chem. 53 (2010) 8260-8273, https://doi.org/10.1021/jm1004545.

[12] N. Bhagavathula, et al., A combination of curcumin and ginger extract improves abrasion wound healing in corticosteroid-impaired hairless rat skin, Wound Repair Regen. 17 (2009) 360-366, https://doi.org/10.1111/j.1524-475X.2009.00483.x.

[13] Y.-T. Huang, Y.-W. Lin, H.-M. Chiu, B.-H. Chiang, Curcumin induces apoptosis of colorectal cancer stem cells by coupling with CD44 marker, J. Agric. Food Chem. 64 (2016) 2247-2253, https://doi.org/10.1021/acs.jafc.5b05649.

[14] L. Zhang, et al., Curcumin-cyclodextrin complexes enhanced the anti-cancer effects of curcumin, Environ. Toxicol. Pharmacol. 48 (2016) 31-38, https://doi.org/10.1016/j.etap.2016.09.021.

[15] J. Chen, et al., Curcumin and its promise as an anticancer drug: an analysis of its anticancer and antifungal effects in cancer and associated complications from invasive fungal infections, Eur. J. Pharmacol. 772 (2016) 33-42, https://doi.org/10.1016/j.ejphar.2015.12.038.

[16] C.F. van Nostrum, Covalently cross-linked amphiphilic block copolymer micelles, Soft Matter 7 (2011) 3246-3259, https://doi.org/10.1039/C0SM00999G.

[17] H. Fessi, F. Puisieux, J.P. Devissaguet, N. Ammoury, S. Benita, Nanocapsule formation by interfacial polymer deposition following solvent displacement, Int. J. Pharm. 55 (1989) R1-R4, https://doi.org/10.1016/0378-5173(89)90281-0. 
[18] H. Fessi, J. Devissaguet, F. Puisieux, C. Thies, Method of formation of colloidal nanoparticles, French Patent 2 (1988) 988.

[19] I. Otsuka, et al., Self-assembly of maltoheptaose-block-polystyrene into micellar nanoparticles and encapsulation of gold nanoparticles, Langmuir 29 (2013) 15224-15230, https://doi.org/10.1021/la403941v.

[20] Liu, Z., Kiessling, F., G\, J., \\#228 \& tjens. Advanced nanomaterials in multimodal imaging: design, functionalization, and biomedical applications. J. Nanomaterials 2010, 1-15, doi:https://doi.org/10.1155/2010/894303 (2010).

[21] A. Petrelli, R. Borsali, S. Fort, S. Halila, Oligosaccharide-based block copolymers: metalfree thiol-maleimide click conjugation and self-assembly into nanoparticles, Carbohydr. Polym. 124 (2015) 109-116, https://doi.org/10.1016/j.carbpol.2015.01.079.

[22] S. de Medeiros Modolon, et al., Sweet block copolymer nanoparticles: preparation and selfassembly of fully oligosaccharide-based amphiphile, Biomacromolecules 13 (2012) 1129-1135, https://doi.org/10.1021/bm3000138.

[23] K.M. Zepon, et al., Glyco-nanoparticles made from self-assembly of maltoheptaoseblockpoly(methyl methacrylate): micelle, reverse micelle, and encapsulation, Biomacromolecules 16 (2015) 2012-2024, https://doi.org/10.1021/acs.biomac.5b00443.

[24] L. Mazzarino, et al., Nanoparticles made from xyloglucan-block-polycaprolactone copolymers: safety assessment for drug delivery, Toxicol. Sci. (2015) https://doi.org/10.1093/toxsci/kfv114.

[25] N.M. Khalil, et al., Pharmacokinetics of curcumin-loaded PLGA and PLGA-PEG blend nanoparticles after oral administration in rats, Colloids Surf. B: Biointerfaces 101 (2013) 353360. https://doi.org/10.1016/j.colsurfb.2012.06.024.

[26] Passirani, C., Barratt, G., Devissaguet, J.-P. \& Labarre, D. Interactions of nanoparticles bearing heparin or dextran covalently bound to poly(methyl methacrylate) with the complement system. Life Sci. 62, 775-785, doi:http://dx.doi.org/10.1016/S0024 3205(97)01175-2 (1998).

[27] Y.-C. Chiu, I. Otsuka, S. Halila, R. Borsali, W.-C. Chen, High-performance nonvolatile transistor memories of pentacence using the green electrets of sugar-based block copolymers and their supramolecules, Adv. Funct. Mater. 24 (2014) 4240-4249, https://doi.org/10.1002/adfm.201304297.

[28] M. Karimi, D. Biria, The promiscuous activity of alpha-amylase in biodegradation of lowdensity polyethylene in a polymer-starch blend, Sci. Rep. 9 (2019) 2612, https://doi.org/10.1038/s41598-019-39366-0. 
[29] M.R. Lorenz, et al., Synthesis of fluorescent Polyisoprene nanoparticles and their uptake into various cells, Macromol. Biosci. 8 (2008) 711-727, https://doi.org/10.1002/ mabi.200700336.

[30] C.-C. Hung, et al., Conception of stretchable resistive memory devices based on nanostructure-controlled carbohydrate-block-polyisoprene block copolymers, Adv. Funct. Mater. 27 (2017), 1606161. https://doi.org/10.1002/adfm.201606161.

[31] I. Otsuka, et al., Thermoresponsive vesicular morphologies obtained by selfassemblies of hybrid oligosaccharide-block-poly(N-isopropylacrylamide) copolymer systems, Langmuir 26 (2010) 2325-2332, https://doi.org/10.1021/la902743y.

[32] V. Filipe, A. Hawe, W. Jiskoot, Critical evaluation of nanoparticle tracking analysis (NTA) by NanoSight for the measurement of nanoparticles and protein aggregates, Pharm. Res. 27 (2010) 796-810, https://doi.org/10.1007/s11095-010-0073-2.

[33] R.A. Dragovic, et al., Sizing and phenotyping of cellular vesicles using nanoparticle tracking analysis, Nanomedicine 7 (2011) 780-788, https://doi.org/10.1016/j.nano.2011.04.003.

[34] A. Saez, M. Guzmán, J. Molpeceres, M.R. Aberturas, Freeze-drying of polycaprolactone and poly(d,l-lactic-glycolic) nanoparticles induce minor particle size changes affecting the oral pharmacokinetics of loaded drugs, Eur. J. Pharm. Biopharm. 50 (2000) 379-387, https://doi.org/10.1016/S0939-6411(00)00125-9.

[35] W. Abdelwahed, G. Degobert, H. Fessi, Investigation of nanocapsules stabilization by amorphous excipients during freeze-drying and storage, Eur. J. Pharm. Biopharm. 63 (2006) 87-94, https://doi.org/10.1016/j.ejpb.2006.01.015.

[36] W. Abdelwahed, G. Degobert, S. Stainmesse, H. Fessi, Freeze-drying of nanoparticles: formulation, process and storage considerations, Adv. Drug Deliv. Rev. 58 (2006) 1688-1713, https://doi.org/10.1016/j.addr.2006.09.017.

[37] A.M. Layre, et al., Freeze-drying of composite Core-Shell nanoparticles, Drug Dev. Ind. Pharm. 32 (2006) 839-846, https://doi.org/10.1080/03639040600685134.

[38] U.M. Musazzi, I. Youm, J.B. Murowchick, M.J. Ezoulin, B.-B.C. Youan, Resveratrolloaded nanocarriers: formulation, optimization, characterization and in vitro toxicity on cochlear cells, Colloids Surf. B: Biointerfaces 118 (2014) 234-242, https://doi.org/10.1016/j.colsurfb.2014.03.054.

[39] S.F. Chow, et al., Development of highly stabilized curcumin nanoparticles by flash nanoprecipitation and lyophilization, Eur. J. Pharm. Biopharm. 94 (2015) 436-449, https://doi.org/10.1016/j.ejpb.2015.06.022. 
[40] L. Mazzarino, I.C. Bellettini, E. Minatti, E. Lemos-Senna, Development and validation of a fluorimetric method to determine curcumin in lipid and polymeric nanocapsule suspensions, Brazilian Journal of Pharmaceutical Sciences 46 (2010) 219-226.

[41] L. Mazzarino, et al., Xyloglucan-block-poly(e-Caprolactone) copolymer nanoparticles coated with chitosan as biocompatible mucoadhesive drug delivery system, Macromol. Biosci. 14 (2014) 709-719, https://doi.org/10.1002/mabi.201300465.

[42] J.F. Piai, Preparação e Caracterização de Complexos Polieletrólitos de Quitosana/Sulfato de Condroitina e Estudos de Liberação Controlada Masters thesis, Universidade Estadual de Maringá, 2008.

[43] K.F.B. Camilo, Complexo pectina/caseína: aspectos basicos e aplicados, $\mathrm{PhD}$ thesis Universidade de São Paulo, 2007.

[44] T. Mosmann, Rapid colorimetric assay for cellular growth and survival: application to proliferation and cytotoxicity assays, J. Immunol. Methods 65 (1983) 55-63, https://doi.org/10.1016/0022-1759(83)90303-4.

[45] S. Kim, J. Xu, Aggregate formation of zein and its structural inversion in aqueous ethanol, J. Cereal Sci. 47 (2008) 1-5, https://doi.org/10.1016/j.jcs.2007.08.004.

[46] A.K. Van Helden, A. Vrij, Static light scattering of concentrated silica dispersions in apolar solvents, J. Colloid Interface Sci. 78 (1980) 312-329, https://doi.org/10.1016/00219797(80)90570-6.

[47] J.K.G. Dhont, C. Smits, H.N.W. Lekkerkerker, A time resolved static light scattering study on nucleation and crystallization in a colloidal system, J. Colloid Interface Sci. 152 (1992) 386401, https://doi.org/10.1016/0021-9797(92)90041-J.

[48] J.N. Nayak, M.I. Aralaguppi, B.V. Kumar Naidu, T.M. Aminabhavi, Thermodynamic properties of water + tetrahydrofuran and water + 1,4-dioxane mixtures at $(303.15,313.15$, and 323.15) K, J. Chem. Eng. Data 49 (2004) 468-474, https://doi.org/10.1021/je030196t.

[49] J.F. Holler, D.A. Skoog, S.R. Crouch, Princípios de Análise Instrumental, 2007.

[50] J.W. Hickey, J.L. Santos, J.-M. Williford, H.-Q. Mao, Control of polymeric nanoparticle size to improve therapeutic delivery, J. Control. Release 219 (2015) 536-547, https://doi.org/10.1016/j.jconrel.2015.10.006.

[51] A.E. James, J.D. Driskell, Monitoring gold nanoparticle conjugation and analysis of biomolecular binding with nanoparticle tracking analysis (NTA) and dynamic light scattering (DLS), Analyst 138 (2013) 1212-1218, https://doi.org/10.1039/C2AN36467K. 
[52] M.Y. Chan, Q.M. Dowling, S.J. Sivananthan, R.M. Kramer, in: Christopher B. Fox (Ed.), Vaccine Adjuvants: Methods and Protocols, Springer New York 2017, pp. 239-252.

[53] D.R. Hristov, et al., Using single nanoparticle tracking obtained by nanophotonic force microscopy to simultaneously characterize nanoparticle size distribution and nanoparticlesurface interactions, Nanoscale 9 (2017) 4524-4535, https://doi.org/10.1039/C6NR09331K.

[54] A. Jain, et al., Galactose engineered solid lipid nanoparticles for targeted delivery of doxorubicin, Colloids Surf. B: Biointerfaces 134 (2015) 47-58, https://doi.org/10.1016/i.colsurfb.2015.06.027.

[55] X. Lin, et al., Disk-like micelles with cylindrical pores from amphiphilic polypeptide block copolymers, Polym. Chem. 7 (2016) 2815-2820, https://doi.org/10.1039/C6PY00152A.

[56] HR, K. M., H, M., M, M. \& H, D. Preparation and Physicochemical Characterization of Biodegradable mPEG-PCL Core-Shell Micelles for Delivery of Artemisinin. vol. 22, 234-243, doi:10.15171/ps.2016.37 (2016).

[57] S. Doktorovova, et al., Trehalose is not a universal solution for solid lipid nanoparticles freeze-drying, Pharm. Dev. Technol. 19 (2014) 922-929, https://doi.org/10.3109/10837450.2013.840846.

[58] A.R.d.V. Morais, et al., Freeze-drying of emulsified systems: a review, Int. J. Pharm. 503 (2016) 102-114, https://doi.org/10.1016/j.ijpharm.2016.02.047.

[59] P. Fonte, S. Reis, B. Sarmento, Facts and evidences on the lyophilization of polymeric nanoparticles for drug delivery, J. Control. Release 225 (2016) 75-86, https://doi.org/10.1016/j.jconrel.2016.01.034.

[60] S. Salatin, S. Maleki Dizaj, A. Yari Khosroushahi, Effect of the surface modification, size, and shape on cellular uptake of nanoparticles, Cell Biol. Int. 39 (2015) 881-890, https://doi.org/10.1002/cbin.10459.

[61] L. Mazzarino, et al., Elaboration of chitosan-coated nanoparticles loaded with curcumin for mucoadhesive applications, J. Colloid Interface Sci. 370 (2012) 58-66, https://doi.org/10.1016/j.jcis.2011.12.063.

[62] V. Sueth-Santiago, G.P. Mendes-Silva, D. Decoté-Ricardo, M.E.F.D. Lima, CURCUMINA, O PÓ DOURADO DO AÇAFRÃO-DA-TERRA: INTROSPECÇÕES SOBREQUÍMICA E ATIVIDADES BIOLÓGICAS, Química Nova 38 (2015) 538-552.

[63] M. Salem, S. Rohani, E.R. Gillies, Curcumin, a promising anti-cancer therapeutic: a review of its chemical properties, bioactivity and approaches to cancer cell delivery, RSC Adv. 4 (2014) 10815-10829, https://doi.org/10.1039/C3RA46396F. 
[64] V.B. Patel, S. Misra, B.B. Patel, A.P. Majumdar, Colorectal Cancer: Chemopreventive role of Curcumin and resveratrol, Nutr. Cancer 62 (2010) 958-967, https://doi.org/10.1080/01635581.2010.510259.

[65] Y.-J. Wang, et al., Stability of curcumin in buffer solutions and characterization of its degradation products, J. Pharm. Biomed. Anal. 15 (1997) 1867-1876, https://doi.org/10.1016/S0731-7085(96)02024-9. 